\title{
Epidemiological History of Cypress Canker Disease in Source and Invasion Sites
}

\author{
Roberto Danti and Gianni Della Rocca * \\ Institute for Sustainable Plant Protection, National Research Council, Via Madonna del Piano 10, \\ Sesto Fiorentino, Florence 50019, Italy; roberto.danti@ipsp.cnr.it \\ * Correspondence: gianni.dellarocca@ipsp.cnr.it; Tel.: +39-055-522-5663
}

Academic Editors: Matteo Garbelotto and Paolo Gonthier Received: 27 February 2017; Accepted: 12 April 2017; Published: 15 April 2017

\begin{abstract}
Seiridium cardinale is a fungal pathogen responsible for pandemic cypress canker disease (CCD). The fungus has shown the ability to infect different hosts in many areas throughout the globe, but its spread and impact were favored by conducive environmental conditions. The most severe epidemics were reported in California and the Mediterranean, the former considered the source area of the pathogen from which the Mediterranean infestation have originated. Here we reconstruct the epidemiological history of the disease in California and the Mediterranean. Evolution of the disease in the two contrasting areas was weighed in relation to differences between the two environments in terms of climate, landscape properties, and adopted management practices. In addition, differences emerged among the source and invasive populations in terms of genetic and phenotypic variability, structure, and mode of reproduction allow a few comments to be made about the environmental implications and related quarantine of new introductory events.
\end{abstract}

Keywords: Seiridium cardinale; fungal pathogen; Cupressus; alien species; landscape properties; population genetic; phenotypic traits; disease management; resistance

\section{Introduction}

The introduction of alien species ranks second only to habitat destruction as one of the major threats to native ecosystems [1,2]. In the case of pathogenic species, lack of co-evolution between hosts and invasive pathogens can result in devastating impacts on the host species [3-5]. As a result of the introduction of alien species, native species can be decimated or displaced, local biodiversity can be dramatically reduced, landscape can be spoiled, and when plants of economic importance are affected, the damage can amount to millions or billions of dollars per year [6-9].

Seiridium cardinale (W.W. Wagener) B. Sutton \& I.A.S. Gibson is a pathogenic fungus responsible for cypress canker-a pandemic disease which has caused significant mortality worldwide in many species of Cupressaceae [10-12]. Cypress canker is also caused by other sister species-S. cupressi (Guba) Boesew. (anamorph of Lepteutypa cupressi (Nattrass, C. Booth \& B. Sutton) H.J. Swart) and S. unicorne (Cooke \& Ellis) B. Sutton-but they are less widespread and aggressive, and their epidemiology has been substantially less studied compared to $S$. cardinale. Therefore, this paper will focus on the most known of the three fungi.

The first epidemic of cypress canker disease (CCD) was reported in California in 1928 on Monterey cypress (Cupressus macrocarpa Hartw. ex Gordon), which over a period of only a few years was wiped out in the plantations located in the inland districts [13]. Mediated by the movement of infected plant material over long distances, in the course of the following decades, the disease spread progressively over the five continents: to New Zealand, France, and Chile; to Italy, Argentina, and Greece [14-19], and subsequently to the entire Mediterranean basin and to other countries in central-northern Europe (UK, Ireland, and Germany), to Canada, North and South Africa, and Australia [20-27]. Cypress canker 
disease has been reported to affect species of Cupressus, Chamaecyparis, Cryptomeria, Juniperus, Thuja, and $\times$ Cupressocyparis $[11,12,28]$.

Although the pathogen has shown the ability to infect different host species and to establish in many countries in which it was introduced, development, impact, and invasiveness of the disease varied in the different countries. Epidemics were certainly favored by climatic conditions suited to the fungal pathogen and by the density and continuity of susceptible hosts [11]. Generally, the Mediterranean climate-which is characterized by a marked seasonality, with a substantial thermal range between summer and winter and by mild rainy and humid springs and autumns-is highly conducive to the development of an epidemic of cypress canker disease [10]. Microclimatic conditions may play a major role in the development of the disease, and also explain the presence of nuclei of the host that have escaped the disease in close proximity to areas that have been severely affected [12]. The occurrence of S. cardinale infections is known to be favored by the presence of small wounds in the periderm through which the conidia or mycelium enter the inner bark. Young trunks and branches are particularly exposed to infections, because they are more greatly subjected to bark injuries due to cold, frost, hail, or to forced growth by fertilizers, insects, rodents, etc. [10].

Though high levels of mortality were experienced in many areas around the globe, spread and impact of the disease were determined by the presence of conducive factors. The disease has even been reported in north-central Europe [21-29] and in SE Alaska and Canada [23-30], where it maintained a sporadic character as the climate is too cold for the rapid spread of the pathogen. On the other hand, the disease was reported in isolated spots in some countries of North Africa [27-31], where the hot and dry climate also slows the spread of the disease. In other countries, such as South Africa and New Zealand [26-32], where climatic conditions are quite similar to the Mediterranean climate, bark canker showed an invasive character, and represented a limiting factor for cypress plantations. After the introduction of the pathogen, CCD assumed the character of a dreadful epidemic, with a high degree of invasiveness and destructiveness in the Mediterranean basin, where both favorable climatic conditions and the continuity and density of the susceptible host (Cupressus sempervirens L.) occurred over a vast territory [11,12].

Studies on population genetics and phenotypic traits enabled comparison of the S. cardinale populations of California and the Mediterranean, the two areas where the pathogen gave rise to the most severe outbreaks [33-35]. It appeared that the Mediterranean cypress canker epidemics stemmed from the introduction of the fungus from California, probably following a single introductory event.

Here we reconstruct the epidemiological history of the disease in California and the Mediterranean. The evolution of the disease in the two contrasting areas is weighed in relation to differences between the two environments in terms of climate, landscape properties, and adopted management practices. In addition, differences emerged among the source and invasive populations in terms of genetic and phenotypic variability, structure, and mode of reproduction, raising a few points about the environmental implications and the related quarantine of new introductory events.

\section{Epidemiology of CCD in California (S. cardinale Source Population)}

Cypress canker disease caused by S. cardinale was identified and described for the first time in Palo Alto around San Francisco Bay (western-central California) by Wagener [13] on Monterey cypress (C. macrocarpa), although evidence has indicated that it had been present there since at least 1885 (Jepson field book). In the following years, the disease was detected in Alameda, Santa Clara, and San Mateo (Sacramento county, report uncertain) counties [13]. During the initial years after these reports, the pathogen epidemic was so violent that more than 30,000 trees of Monterey and Common cypress (C. sempervirens) were killed [36]. In California, San Francisco and Los Angeles-the two main ports along the Californian pacific coast—were identified as the two main foci of the disease [37].

Since its first report, the disease assumed major epidemic proportions in many districts through the western half of California and practically wiped out most inland plantations of Monterey cypress [37]. As reported by Wagener in 1928, based on the natural spread of infections, in California the main host 
species of S. cardinale were: C. macrocarpa, C. sempervirens, C. pygmaea Sarg., C. forbesii Jeps., C. lusitanica Mill., Thuja orientalis L., Ch. Lawsoniana Murray Parl., Calocedrus Decurrens Florin, Juniperus chinensis L. var. femina, and J. sabina L. var. tamariscifolia. No traces of the pathogen were found in the natural range of some Californian Cupressus species, including C. macrocarpa and C. bakeri Jeps., C. macnabiana Murray, C. pygmaea, C. forbesii, as well as in natural stands of others Cupressaceae, such as Cal. decurrens, Ch. lawsoniana, J. occidentalis Hook., and J. californica Carr. [37].

In spite of the efforts pursued between 1936 and 1939 to eradicate all cases of the disease in numerous plantings [37], losses from cypress mortality in California were extensive. Eight years after the identification of the disease, three-fourths of all planted Monterey cypress and a considerable number of other susceptible species (e.g., Common cypress) were estimated to be lost as a result of $S$. cardinale attacks $[37,38]$. These heavy wholesale losses resulted in the substitution of cypress windbreak around citrus groves with other tree species, such as Eucalyptus sp. [38].

No more studies dealt with the epidemiology of the cypress canker in California after 1939, when the limits of its geographic spread limits were Glenn County in the Sacramento Valley, as isolated infection centre, Sonoma county as area generally infected (North), San Diego county (South), Sacramento, and San Joaquin county (inland/East) [37] (Figure 1). After this first outbreak, cypresses have not been used for extensive plantings in California, but they were still planted for hedges or as shade trees or, in some cases, for protective purposes, e.g., C. macrocarpa along the coastal area.
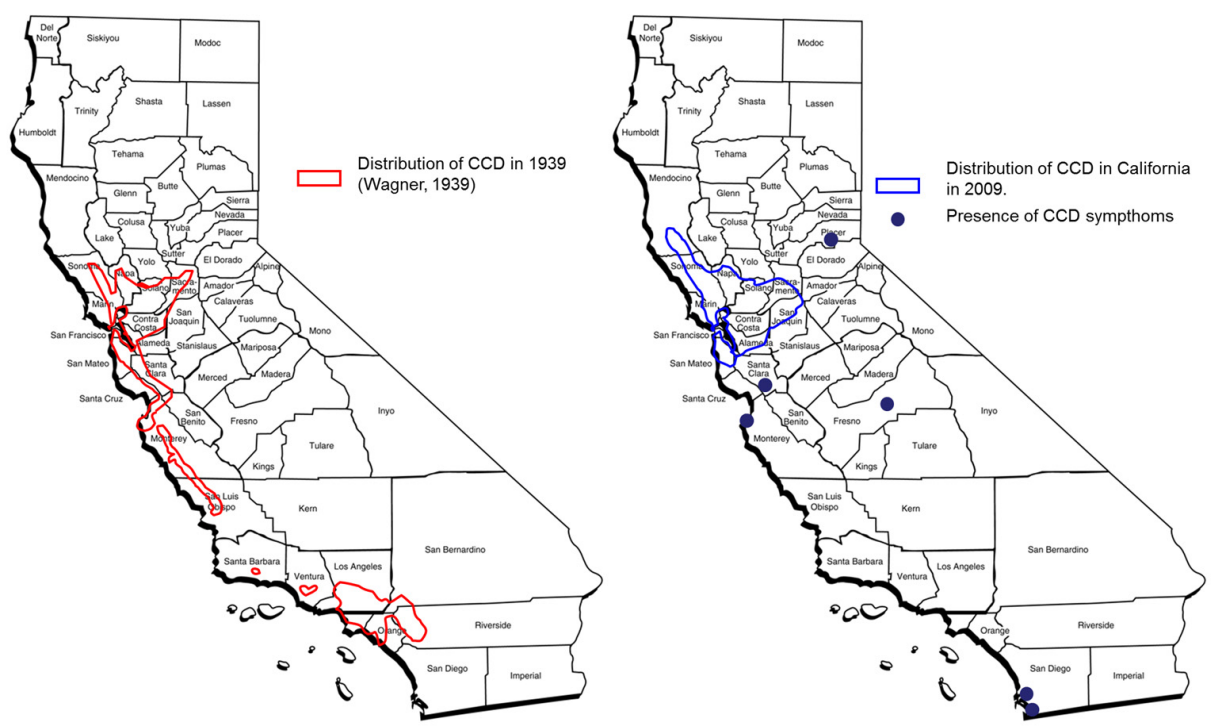

Figure 1. Spread of Seiridium cardinale in California. Maps of distribution of cypress canker disease (CCD) in 1939 and in 2009.

Today, both S. cardinale and S. unicorne are known to be present in California [33-39], threatening ornamental plantations of Cupressus sp.-mainly C. sempervirens, C. macrocarpa, $\times$ Cup. leylandii, and Juniperus spp.

The current spread of CCD in California has been determined by surveying locations where its main hosts are present, such as C. sempervirens, C. macrocarpa, and $\times$ Cup. leylandii during early summer 2009 (Figure 1). The survey included ground determination of infected trees along freeways and national roads, particularly focusing beyond the $S$. cardinale distribution sites reported by Wagener in the 1930s. Many locations were also taken into consideration following reports of local advisors, extension specialists in plant pathology from UC Berkeley, and homeowners. The following counties were covered during the survey: Mendocino, Sonoma, Napa, Marin, Contra Costa, Alameda, Sacramento, El Dorado, San Joaquin, San Francisco, San Mateo, Santa Clara, Stanislaus, Mercedes, Madera, Fresno, Monterey, Tulare, Kern, San Luis Obispo, Orange, Los Angeles, and San Diego. A total 
of 2385 trees of C. sempervirens (790), C. macrocarpa (611) (Figure 2), and $\times$ Cup. leylandii (984) were surveyed for the presence of bark canker infection in 24 counties of California (Table 1). An incidence rate of $11.7 \%$ of $S$. cardinale was recorded.

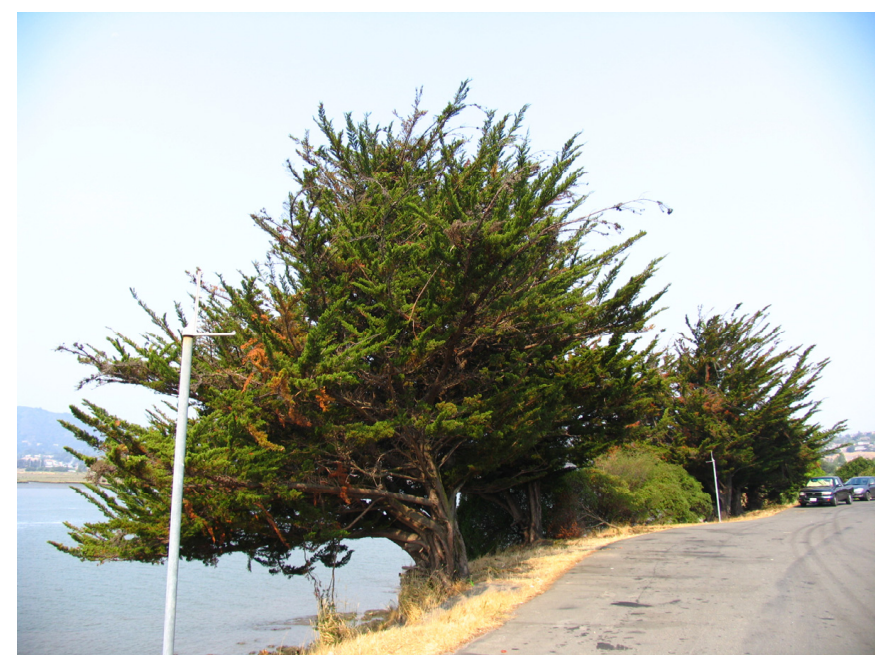

Figure 2. Cupressus macrocarpa affected by CCD in Marin county (California, CA, USA) (2009). Monterey cypress is the major host of CCD in California.

Table 1. CCD incidence per county and host species resulting from the survey conducted in California in 2009 (Della Rocca and Garbelotto, unpublished).

\begin{tabular}{|c|c|c|c|}
\hline County & Host & \% Infected Trees Per Species & $\%$ of Diseased Trees in the County \\
\hline Mendocino & $\times$ Cup. leylandii & 11.4 & 11.4 \\
\hline \multirow{3}{*}{ Sonoma } & $\times$ Cup. leylandii & 19 & \\
\hline & C. sempervirens & 12.1 & 12.9 \\
\hline & C. macrocarpa & 7.7 & - \\
\hline \multirow{2}{*}{ Napa } & $\times$ Cup. leylandii & 13.5 & 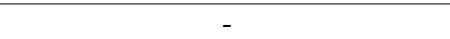 \\
\hline & C. sempervirens & 17.2 & 15.3 \\
\hline \multirow{3}{*}{ Marin } & $\times$ Cup. leylandii & 23.2 & - \\
\hline & C. sempervirens & 3.2 & - \\
\hline & C. macrocarpa & 17.9 & 14.8 \\
\hline \multirow{3}{*}{ Contra Costa } & $\times$ Cup. leylandii & 29.4 & - \\
\hline & C. sempervirens & 1.2 & - \\
\hline & C. macrocarpa & 26.2 & 18.9 \\
\hline \multirow[b]{2}{*}{ Alameda } & C. sempervirens & 1.6 & - \\
\hline & C. macrocarpa & 25 & 13.3 \\
\hline \multirow{2}{*}{ San Joaquin } & $\times$ Cup. leylandii & 34.6 & - \\
\hline & C. sempervirens & 1.7 & 18.1 \\
\hline \multirow{2}{*}{ San Francisco } & C. sempervirens & 3.6 & - \\
\hline & C. macrocarpa & 7.1 & 5.4 \\
\hline \multirow{2}{*}{ San Mateo } & $\times$ Cup. leylandii & 32.1 & - \\
\hline & C. macrocarpa & 21.6 & 26.9 \\
\hline San Diego & $\times$ Cup. leylandii & 3.9 & 3.9 \\
\hline \multirow{2}{*}{ Monterey } & C. sempervirens & 3.3 & - \\
\hline & C. macrocarpa & 2.8 & 3.1 \\
\hline Orange & C. sempervirens & 1.4 & - \\
\hline \multirow{2}{*}{ Los Angeles } & $\times$ Cup. leylandii & 3.3 & - \\
\hline & C. sempervirens & 3.8 & 3.6 \\
\hline \multirow{2}{*}{ San Luis Obispo } & C. sempervirens & 4.3 & - \\
\hline & C. macrocarpa & 12.7 & 8.5 \\
\hline \multirow{2}{*}{ Tulare } & $\times$ Cup. leylandii & 4.4 & . \\
\hline & C. sempervirens & 3.1 & 3.8 \\
\hline
\end{tabular}


The highest disease incidence was scored on Leyland cypress, ranging from $34.6 \%$ to $3.3 \%$ in San Joaquin and Los Angeles counties, respectively. In Monterey cypress, incidence of the disease ranged from $26.2 \%$ in Contra Costa to $2.8 \%$ in Monterey; and in Common cypress, incidence ranged from $17.2 \%$ in Napa to $1.2 \%$ in Contra Costa. The incidence rate was highly variable among counties, depending on ecology and host density at the local level (Table 1). The relationship between the mean percentage of diseased trees and the density of cypresses in an area surveyed in a given county resulted significant (Pearson correlation coefficient $r=0.807 ; n=15 ; p=0.01$ ). In general, disease incidence decreased with the distance (both northward and southward) from the area surrounding San Francisco Bay, which seemed to represent the centre of gravity of the disease.

Today, common cypress is widely used in inland central California, strictly for ornamental purposes: single or in small groups in parks, gardens, flowerbeds, or in rows along some country drives to form hedges, and accompanying catholic sacred places. In this species, the highest incidence of cypress canker was found where it had been planted at higher frequencies, such as in some rural areas of the Sacramento valley and in the Napa and Sonoma valleys. Cupressus sempervirens is less common near to the coast due to the colder climate and sea spray. In northern counties (Humboldt, Trinity, Mendocino), C. sempervirens is rare due to the cold winter, whereas in southern counties such as Los Angeles and San Diego it is quite uncommon and replaced with palms in the landscape, because of the hot and dry desert climate.

The highest disease incidence in Monterey cypress was around the San Francisco bay area, where it reached 25\% and 26.2\% in Alameda and Contra Costa counties, respectively, while lower incidence was recorded in the southern county except for San Luis Obispo county, where it was still relatively high (12.7\%) (Table 1). No CCD symptoms were observed in the native area of Monterey cypress in Monterey and Santa Cruz coastland, where few S. cardinale symptoms were observed only in common cypress. Monterey cypress is broadly spread along the central-northern Pacific coast of the State, where it has been successfully planted (sometimes naturalized) for protective purposes thanks to its tolerance to the strong wind and sea spray (Table 1).

Leyland cypress is a fast-growing evergreen hybrid used extensively in horticulture for hedges and screens to enforce privacy. It is very frequently planted in private gardens around cottages, pruned at 2-3 m height to form a "green barrier" in coastal and inland areas of California. Infected trees of Leyland cypress were found everywhere irrespective of geography, age, and host density. The highest incidence of the disease in that hybrid were noted in San Joaquin (34.6\%) and San Mateo (32.1\%) counties.

In California, larvae of cypress bark moth Laspeyresia cupressana (Kearf) frequently mine the border of cankers-mostly on $\times$ Cup. leylandii. From our observations, Phloeosinus cupressi Hopkins and Phloeosinus cristatus (LeConte) - both larger than the European beetles of the same genus-have likely played a marginal role in the spread of the disease.

\section{Epidemiology of CCD in the Mediterranean (S. cardinale Invasive Population)}

\subsection{CCD in Italy}

As described by Moriondo and Bonifacio [40], in 1968, cypress canker had already spread throughout Italy, with the exception of Sicily. First reported in Florence (1951), CCD appeared few years later in Latina (1954), and then the disease rapidly spread throughout Italy: to north and north-east (Treviso 1958), (Friuli-Venezia Giulia and Lombardy, both in 1961); while southward CCD was first reported in Rome (1961), Basilicata (Matera, 1964), and Calabria (1965). In 10-15 years, the disease spread in distances of $300 \mathrm{~km}$ northward and $700 \mathrm{~km}$ southward, and also crossed the Tyrrhenian Sea (Sardinia in 1961), suggesting an important role for human activity in transporting the pathogen.

The first picture of disease incidence available at the national level was based on a map reported by Panconesi [10] (Figure 3). According to this map, the most affected region was Tuscany, with an incidence higher than $30 \%$ around Florence, and from $21 \%$ to $30 \%$ in the surrounding provinces of Pistoia, Arezzo, and Siena. The map indicated that the incidence of cypress canker was highest in 
the areas of the countries where cypress was most widespread (Tuscany, Liguria, Lazio, Campania, around the pre-Alpine lakes), while the impact of the disease remained low ( $1 \%-10 \%$ incidence) in regions where cypress was scattered or sporadically distributed.

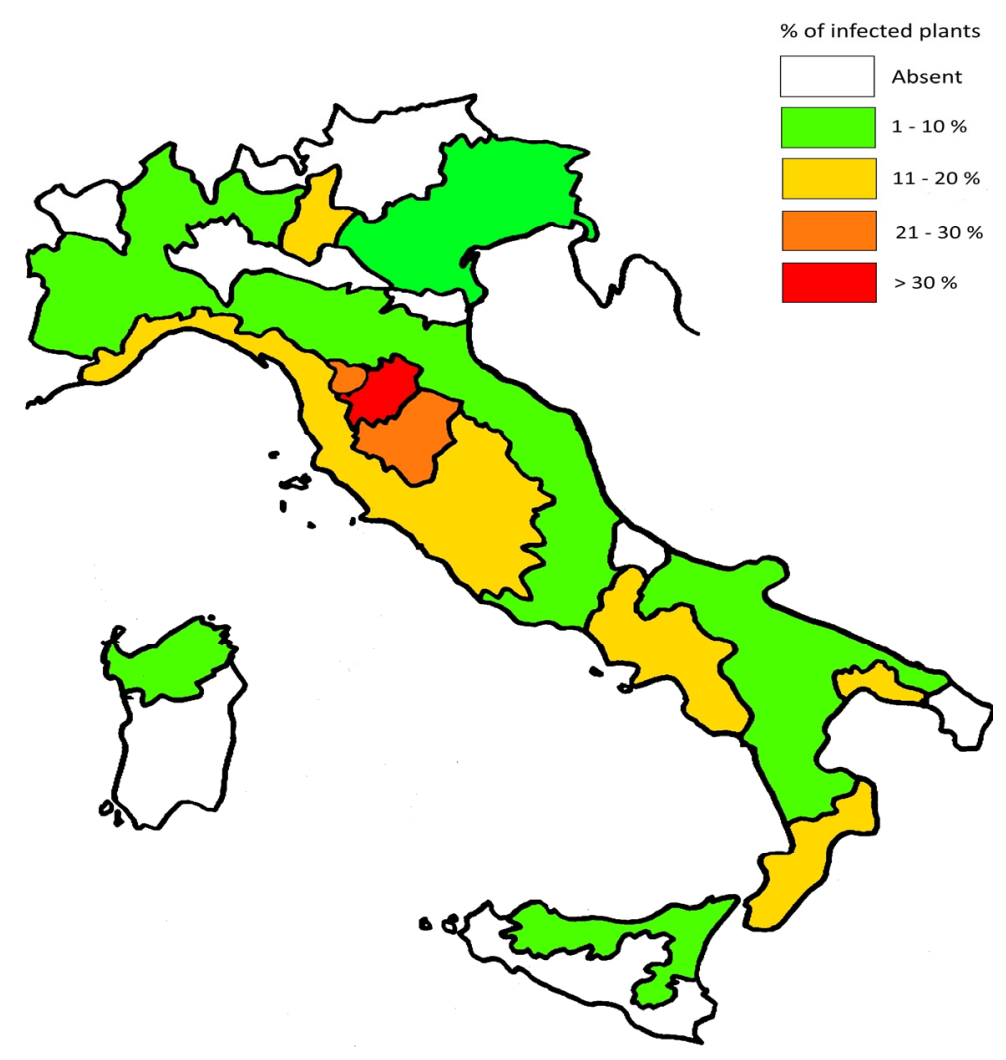

Figure 3. Incidence of CCD in Italy in 1988 according to Panconesi ([10], modified).

Despite many reports of the disease all around the world, a long-term epidemiological story can be approached only in Tuscany (central Italy). Common cypress is a representative element of the Italian cultural landscape, and plays an iconic role in Tuscany. It has traditionally been of primary importance in historical parks and gardens, villas, and boulevards, around farmhouses and sacred spots, along hillsides, and as a landmark in the countryside. Common cypress has also been successfully used for reforestation, aimed at soil protection in degraded and drought-stressed sites, and for the establishment of windbreaks and hedges. In Tuscany, the most important national nursery district located in Pistoia was the likely entrance of the disease. Then, abundance and spatial continuity of the pathogen's main host in the surrounding forests and ornamental plantations promoted its spread.

In the few years after its introduction, the pathogen became a real threat to cypress. During the 1960s, cypress canker disease started to show its destructiveness, causing high mortality. From then on, the developing epidemics attracted the attention of many specialists. The spread of the disease was recorded by a series of surveys aimed at planning proper control measures throughout the regional territory.

A geographical distribution of CCD from 1967 to 1975 in Tuscany was reported by Bartoloni et al. [41]. The maps in Figure 4 show the evolution of the disease over a period of 8 years, showing that from initial nuclei of the disease-mainly located in the provinces of Florence, Livorno and Lucca-the disease quickly spread south-eastward to the provinces of Arezzo, Siena, Grosseto, and Pistoia. 


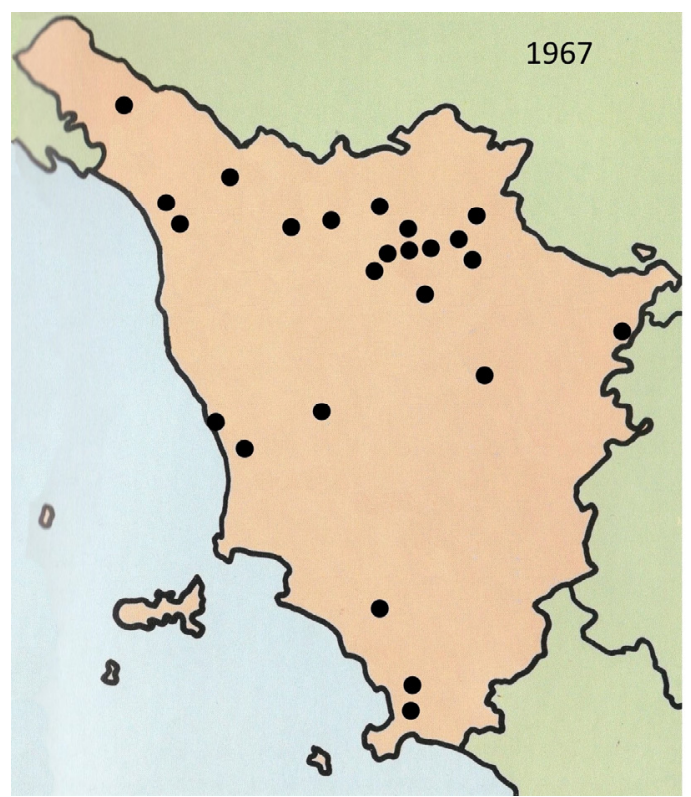

(A)

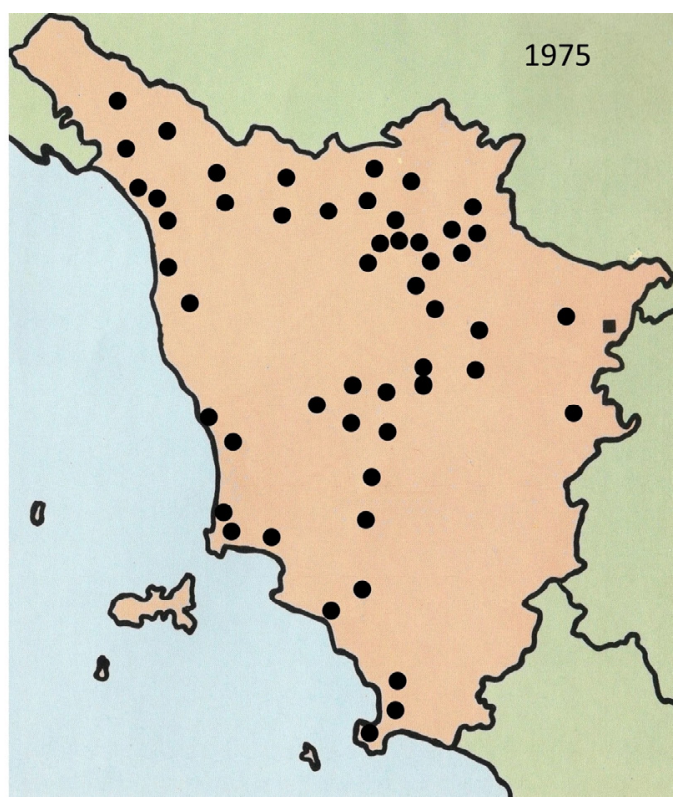

(B)

Figure 4. Maps of the incidence distribution of CCD in Tuscany in 1967 (A) and 1975 (B) according to Bartoloni et al. [41] (modified).

The first systematic survey of the disease was carried out in the province of Florence in 1978 [42]. A total of 235 cypress stands and 3,884,050 trees were examined, covering an area of 3575 ha. The mean incidence of the disease in the province of Florence was $14.5 \%$, ranging from $1 \%$ to $30 \%$. In woodlands, the incidence was a little lower than in ornamental plantations $(12.4 \%$ and $16 \%$, respectively). A negative correlation between elevation and incidence of CCD was found for the ornamental plantations ( $r=-0.560, n=49$ sites). A higher mean incidence (20.4\%) of CCD was found in the sites located between $50 \mathrm{~m}$ and $200 \mathrm{~m}$, while a lower mean value $(9.9 \%)$ was recorded in sites located above $350 \mathrm{~m}$ Moreover, a positive correlation ( $r=0.286, n=50$ municipalities) was observed between the abundance of cypress trees in each site and the recorded incidence of the disease.

This survey followed a series of extensive sanitation campaigns that had been conducted since 1973 in an attempt to control the disease, with more than 40,000 trees felled, about 20,000 that were pruned (to remove the cankered tissues from the crown), and almost 200,000 that were preventively treated with Bordeaux mixture (the poor effectiveness of copper compounds for protecting cypress from bark canker was later revealed in [43]) [42,44,45].

Based on the available data, a time course curve of the incidence of the disease in the Province of Florence from its appearance in 1951 to 1991 was reconstructed by [46] (Figure 5). The plotted data formed a saturation curve that is typical of the epidemic spread of polyetic diseases. This suggests an initial phase of spread in which the disease incidence increased relatively slowly (up to the mid-1970s), followed by a second phase of rapid increase of the rate of diseased plants (until the mid-1980s), followed by a third phase when the proportion of diseased trees reached a plateau. The threshold value at which the number of new infections started to increase at a higher rate seems to be around $15 \%-20 \%$. A mean incidence of the disease of $40 \%$ for the entire provincial territory (Figure 5) appeared to be an overestimate, and could be due to the monitoring network being unevenly distributed throughout the territory. 


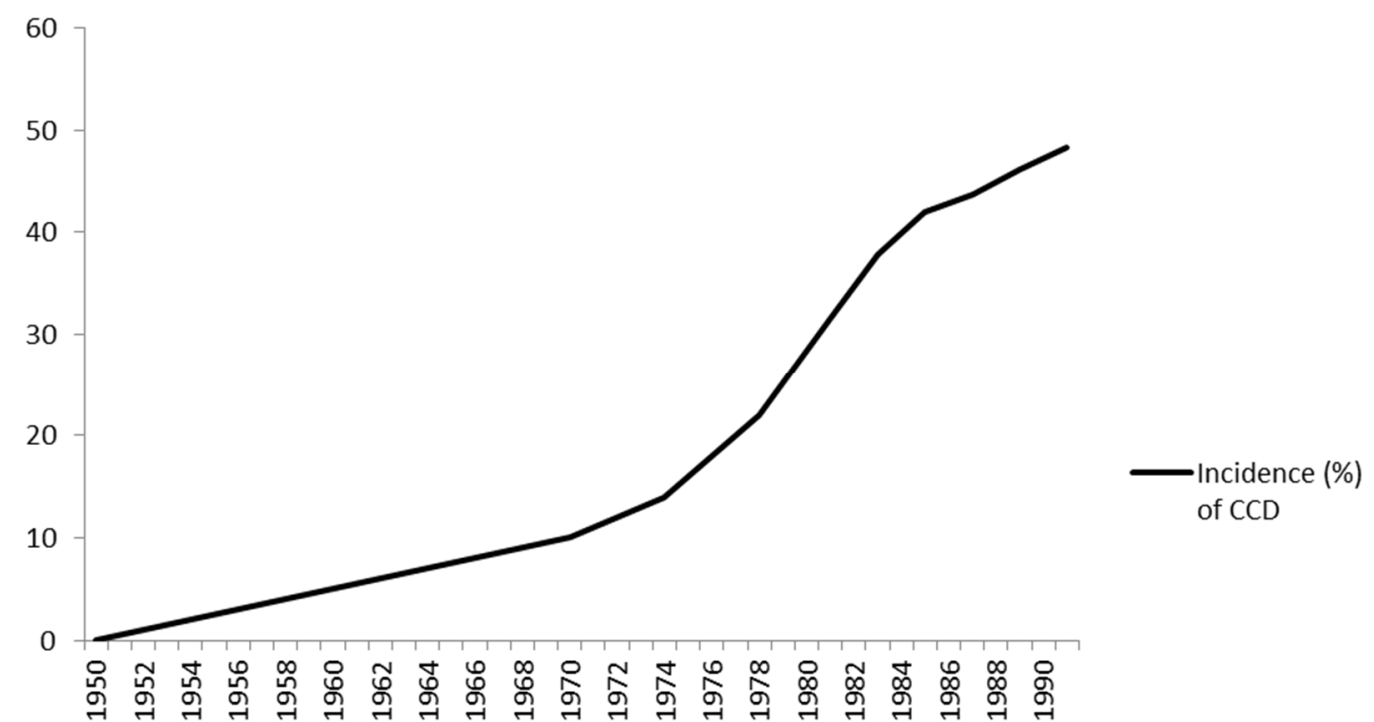

Figure 5. Evolution of the incidence of CCD in the Florence district from its first report in 1951 to 1991 according to Panconesi and Raddi (adapted from [46]).

Among the vectors of the pathogen, the bark beetles Phloeosinus aubei (Perris), P. thuje (Perris), and P. armatus (Reitter), the cypress seed bug Orsillus maculatus (Fieber) and the cypress bark moth Cydia cupressana Kearfott may have played a significant role in the spread of the disease, although their quantitative effect has not yet been defined. In particular, the bark beetle that breeds on infected crowns and then moves to surrounding healthy trees for feeding is well-known to be a carrier of the fungal inoculum contributing to the spread of infections to new host trees. This role is presumed to have been more important during the epidemic phase of the disease, as the number of infected dead or dying plants was rapidly increasing. The extensive survey carried out in 1994 across the region [47] by the National Forest Service of Italy (3,577,000 cypress trees in 2657 sampled areas) showed a mean incidence of $26.4 \%$, ranging from $12.7 \%$ to $53.1 \%$ in the provinces of Siena and Massa Carrara, respectively (Table 2). The CCD was found in $93 \%$ of the sampled areas, showing that the disease had spread throughout the entire region, despite the control measures that had been adopted.

Table 2. Mean CCD disease incidence per province in Tuscany in 1994 resulting from a detailed survey carried out by the Italian National Forest Service, according to Pivi [47].

\begin{tabular}{cc}
\hline Province & Bark Canker Incidence (\%) \\
\hline Arezzo & 32.4 \\
Florence & 27.6 \\
Grosseto & 26.4 \\
Livorno & 24.8 \\
Lucca & 25.3 \\
Massa Carrara & 53.1 \\
Pisa & 18.2 \\
Pistoia & 17.1 \\
Siena & 12.7 \\
Regional mean & 26.4 \\
\hline
\end{tabular}

From 2000 to 2009, the META service (Regional Monitoring Network of Forest Health) of the Tuscan Regional Administration that is focussed on the monitoring of forests to plan proper protection measures included S. cardinale as a major forest pathogen. A network of 150 sampling areas distributed to cover all the provinces of the Tuscan region were used to monitor the evolution of the pathogen (Table 3) (2009). During this period, a slow decrease in disease incidence was reported in most of 
the provinces, and the regional mean value substantially dropped from $28.0 \%$ in 2002 to $20.6 \%$ in 2009. When the single provinces were considered, a lower mean value of $8.2 \%$ was recorded for Massa Carrara, whereas the highest mean value of 38.9\% was recorded for Arezzo (Figures 6 and 7). Annual variations of the regional means of incidence can be also ascribed to some changes in the monitoring network. Since 2009, no other extended monitoring campaigns were conducted in Tuscany.
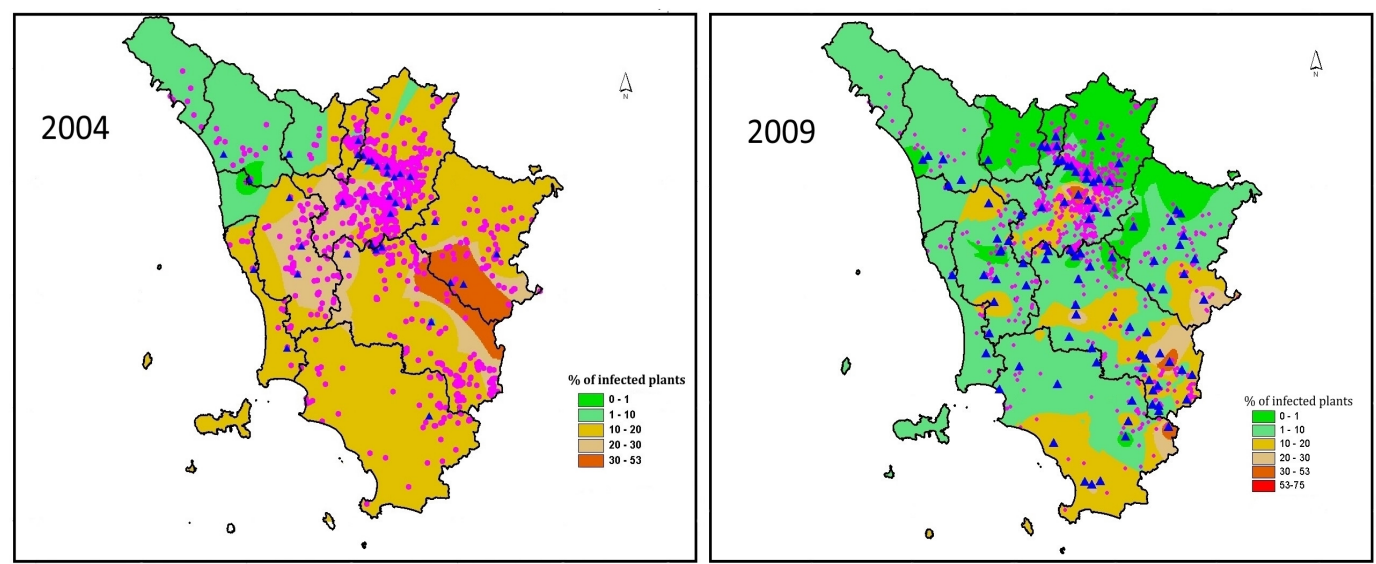

Figure 6. Maps of CCD incidence in Tuscany according to the Regional Monitoring Network of Forest Health (META) service in 2004 and 2009. The discrepancy is due to a decrease of new attacks, but also to a change of the monitoring network (courtesy of Paolo Capretti).

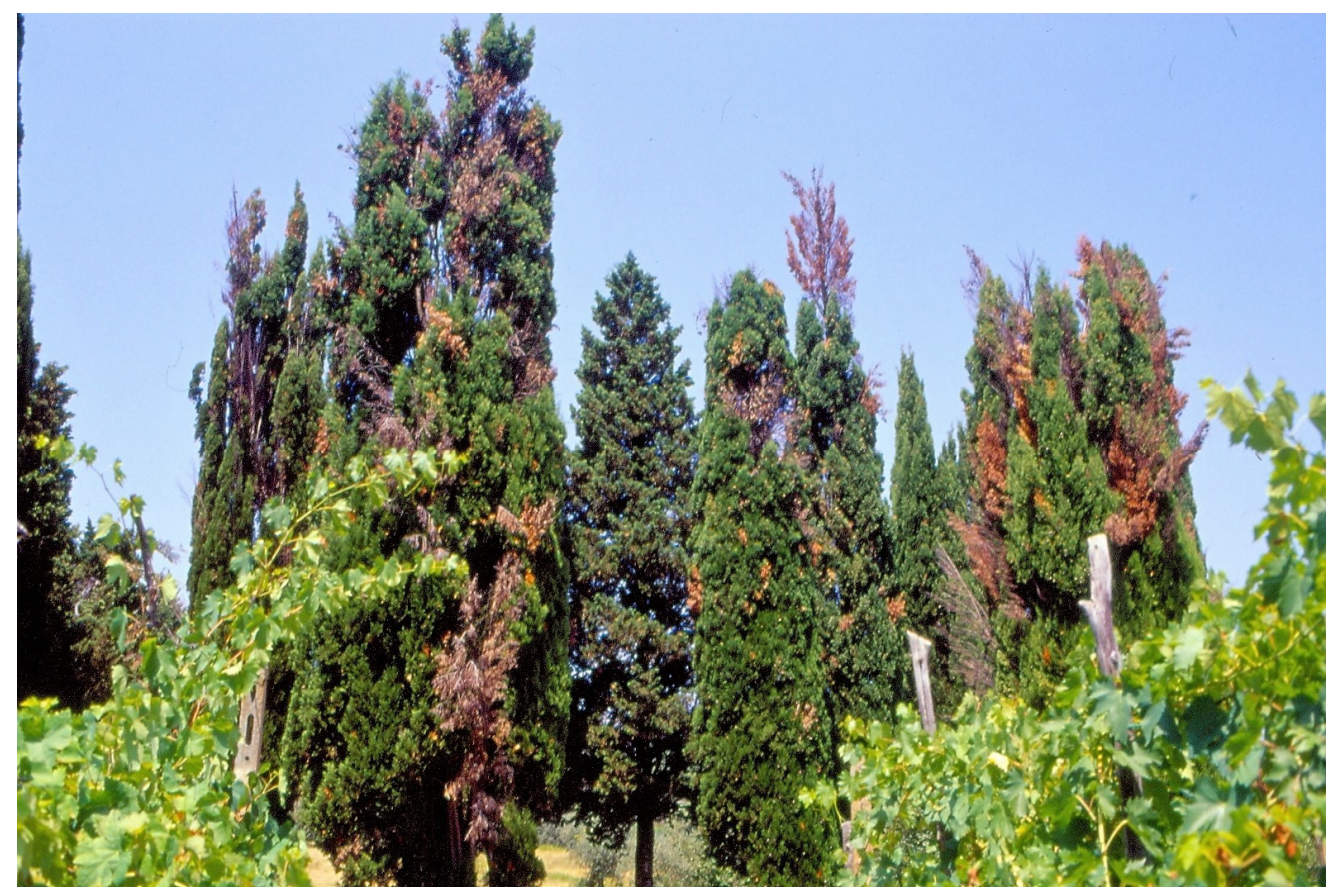

Figure 7. Severe attacks of CCD on Cupressus sempervirens in Guarniente (Arezzo province, Italy) (2003). 
Table 3. Bark canker incidence (\%).

\begin{tabular}{|c|c|c|c|c|c|c|c|}
\hline & 2002 & 2004 & 2005 & 2006 & 2007 & 2009 & $\begin{array}{l}\text { Mean for Province } \\
\quad(2002-2009)\end{array}$ \\
\hline Arezzo & 36.8 & $\begin{array}{c}30.3 \\
(7.3-77.3)\end{array}$ & $\begin{array}{c}55.8 \\
(7.3-100)\end{array}$ & $\begin{array}{c}34.9 \\
(6.3-94)\end{array}$ & $\begin{array}{c}40.2 \\
(3.1-85.2)\end{array}$ & $\begin{array}{c}35.6 \\
(1.8-58.8)\end{array}$ & 38.9 \\
\hline Florence & $\begin{array}{c}20.0 \\
(0-52.9)\end{array}$ & $\begin{array}{c}18.9 \\
(7.5-29.5)\end{array}$ & $\begin{array}{c}30.4 \\
(4.8-84)\end{array}$ & $\begin{array}{c}32.2 \\
(4.8-62)\end{array}$ & - & $\begin{array}{c}21.2 \\
(2.7-90.5)\end{array}$ & 24.5 \\
\hline Grosseto & - & 19.4 & - & - & $\begin{array}{c}28.2 \\
(15.6-47)\end{array}$ & $\begin{array}{c}19.9 \\
(0-40.7)\end{array}$ & 22.5 \\
\hline Livorno & 18.5 & 16.7 & - & - & - & 14.8 & 16.7 \\
\hline Lucca & - & $\begin{array}{c}21.0 \\
(0-38.6)\end{array}$ & - & 8.9 & $\begin{array}{c}5.3 \\
(3.1-7.9)\end{array}$ & $\begin{array}{c}18.1 \\
(5.7-32)\end{array}$ & 13.3 \\
\hline Massa Carrara & - & - & 8.2 & - & - & - & 8.2 \\
\hline Pisa & - & - & $\begin{array}{c}28.6 \\
(13-42.6)\end{array}$ & - & 28.2 & - & 28.4 \\
\hline Prato* & 42.9 & - & 25.6 & 6.1 & 7.9 & $13.4(0-25)$ & 19.2 \\
\hline Siena & $\begin{array}{c}21.8 \\
(3.1-32.8)\end{array}$ & 17.5 & 28.8 & $\begin{array}{c}34.1 \\
(12.5-83.9)\end{array}$ & $\begin{array}{c}23.8 \\
(6-41.2)\end{array}$ & $\begin{array}{c}21.3 \\
(1.9-74)\end{array}$ & 24.5 \\
\hline Regional mean & 28.0 & 20.6 & 29.6 & 23.2 & 22.3 & 20.6 & - \\
\hline
\end{tabular}

A study using G.I.S. applications was conducted at the local level in Tuscany to relate the presence of the disease to climatic and environmental parameters [48]. In a north-to-south $70 \mathrm{~km}$ transect along a main road through Florence, 5000 cypress plants were monitored and georeferenced. The main results showed that the incidence of the disease was generally higher in the southern and western slopes $(22 \%-24 \%$ and $19 \%-21 \%$, respectively). At higher altitudes ( $400-500 \mathrm{~m})$, most of the diseased trees were observed in the south-east, south, and south-west slopes; while at lower altitudes (less than $300 \mathrm{~m}$ ), the incidence was higher in the north-west, north, and north-east slopes. Excluding the effect of other local factors, this confirmed that the fungus prefers mild temperatures (its optimum in vitro is $25^{\circ} \mathrm{C}$ ) and that it is less adapted to both colder and warmer sites.

In the same study [48], a higher incidence was recorded in adult rather than young trees $(87.3 \%$ and $12.3 \%$, respectively), and the proximity to other cypress plants was significant: with $46.4 \%$ of diseased plants growing in groups, $43.8 \%$ in rows, and only $9.6 \%$ of the infected trees growing in isolation. This supports the suggestion that at landscape level, the pattern of distribution of the host may be a feature driving the epidemiology of CCD.

\section{2. $C C D$ in Greece}

In a manner similar to California and central Italy, in Greece, cypress canker assumed epidemic proportions a few years after its introduction in 1962 [18]. In 1975, the disease was reported to be rapidly spreading throughout the country, affecting trees planted outside the natural range of C. sempervirens. The incidence was again related to the climatic conditions of the different districts. In 1985, the most affected areas were the western coast (including the Ionian islands) exposed to humid winds, where incidences of CCD ranged from $1 \%-25 \%$, to over $50 \%$ recorded in the Peloponnese. In the eastern part of the country (characterized by a drier climate), the disease was sporadically reported, with the exception of the island of Eubea. Incidence jumped dramatically in sites where microclimatic conditions were particularly favorable (small humid valleys or higher elevation exposed to cold winter winds), reaching values as high as $80 \%$ in southern Peloponnese and 95\% in Eubea [49] (Figure 8). The same authors observed in Greece what had already been reported in Tuscany: once an incidence threshold of $20 \%$ had been exceeded, the rate of the spread of the disease increased more rapidly according to a saturation curve, suggesting the existence of a kind of ecological quorum over which cypress canker acquires a true epidemic behavior. 


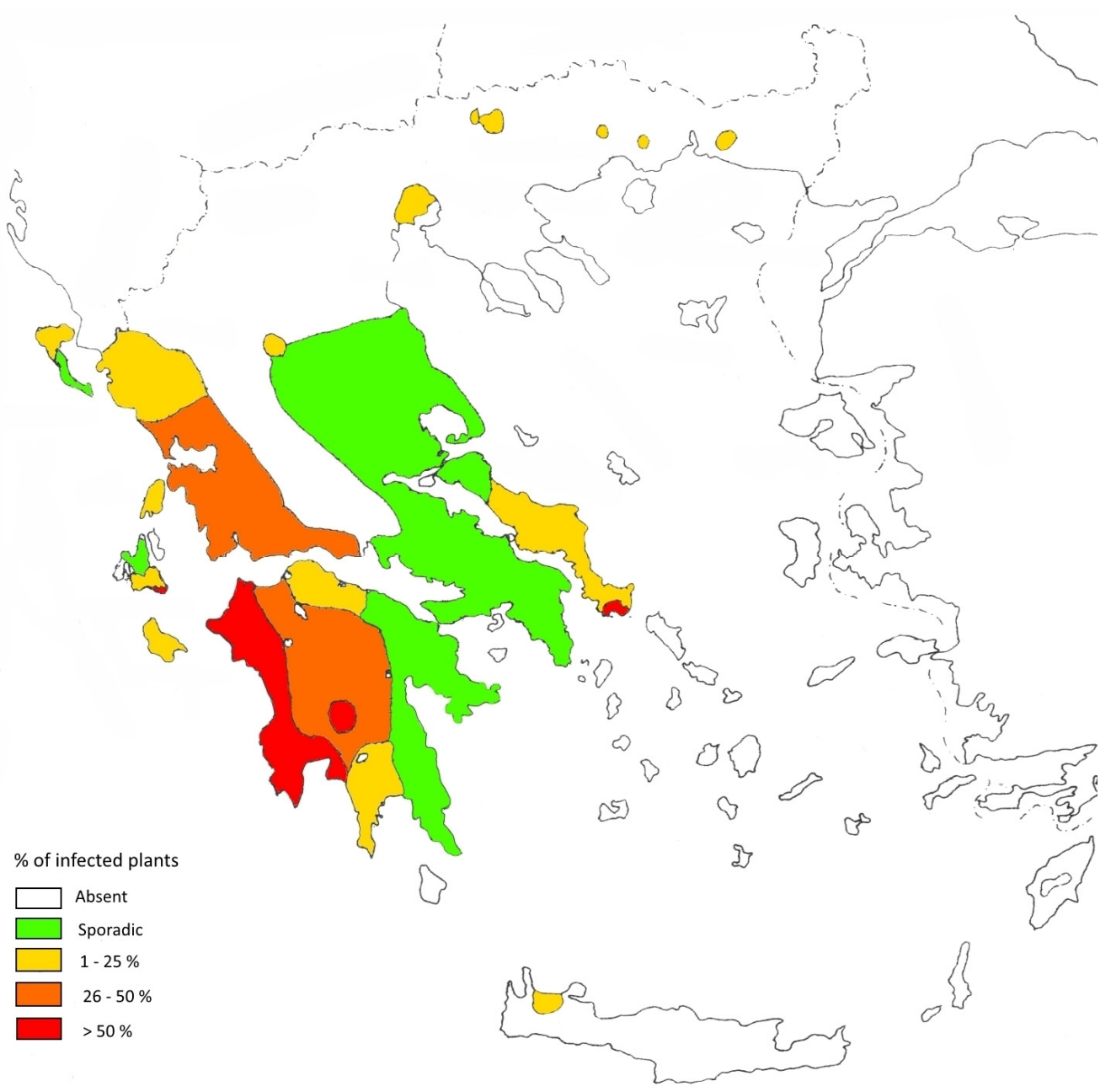

Figure 8. Map of CCD incidence in Greece in 1984 according to Xenopoulos and Diamandis (adapted from [49]).

\section{Landscape Properties Influencing the CCD Epidemic}

Landscape ecology focuses on the influence of habitat heterogeneity in space and time on ecological processes, and hence the impact of the landscape properties on disease dynamics. A reduction of disease risk (and incidence) is generally empirically observed in highly fragmented and diversified landscapes.

In some cases, fragmentation may have positive effects on disease dynamics by increasing the edge-to-surface ratio, thus exposing the host plants that are close to the edge to the inoculum of the pathogen present in the environment (edge effect) [50,51].

Introduction of S. cardinale in the Mediterranean resulted in the rebuilding of a plant-pathogen system that had already been established in California in a different geographical area. The fungus came into contact with a huge population of a susceptible host (four million cypresses in the province of Florence). The frequent distribution of cypress in patches represented by woods and groves with the presence of corridors of cypresses planted in rows along the roads acting as strips of habitat for the fungus likely promoted the movement of the pathogen and favored a large gene flow at a landscape level [52].

The frequent presence of cypresses planted in rows-an element that strongly characterizes the Tuscan landscape-has probably contributed to the spread of disease by favoring the exposure of trees to the inoculum of the fungus, maximizing the edge effect (Figure 9). Host fragmentation represented by frequent patches connected by strips of habitat (corridors), and the local abundance of 
source habitats (plantations of the hyper-susceptible Leyland cypress) may favor a large gene flow that facilitates the spread of virulent strains of $S$. cardinale.

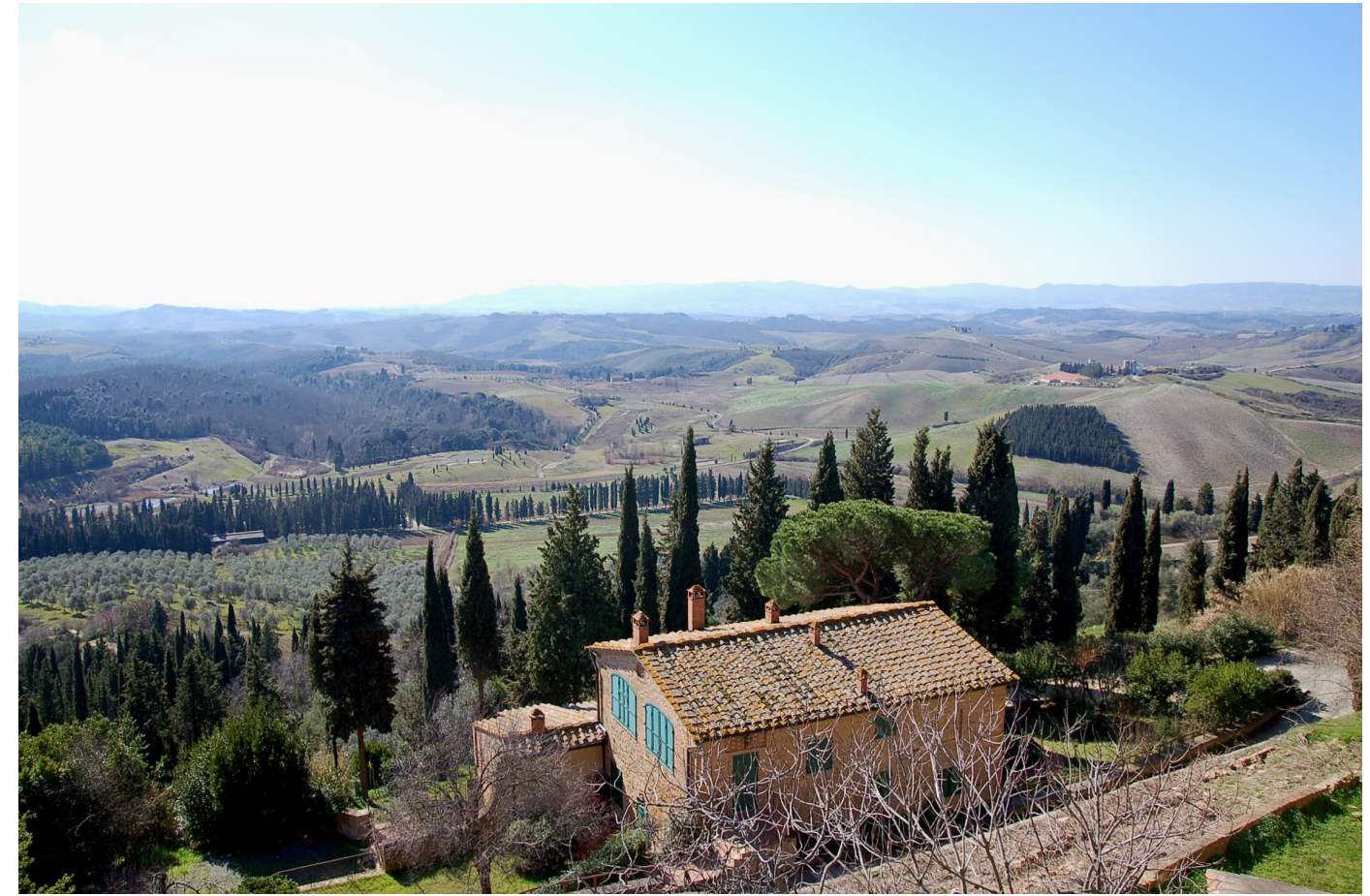

Figure 9. Patches and rows of cypress are key element of the Tuscan landscape: exposure of trees to the inoculum of the fungus is maximized and favored the spread of the fungus.

Inoculum density is considered by plant pathologists as a major factor determining the probability of occurrence and the severity of disease epidemics. The local abundance of source habitats and refuges has been proven to strongly influence the prevalence of a disease. This suggests the importance of landscape composition on the dynamics of at least some diseases [51]. Currently, Leyland cypress plantations may act as a reservoir of inoculum that may influence the propagule pressure of $S$. cardinale in central Italy (Figure 10). Besides being used as an ornamental, in groups or in hedges, Leyland cypress has been extensively planted throughout the country to screen highways, main roads, railway lines, infrastructures and industrial buildings. In the last decade, from north to south, severe diebacks and mortality due to $S$. cardinale canker have been observed with increasing frequency on disfigured Leyland cypress plantations. In a survey recently carried out in a representative sample area around Florence, incidence of bark canker on Leyland cypress was higher than $54 \%$, with more than $11 \%$ of trees killed [28]. Leyland cypress is typically planted in long rows, which could act as continuous strips of habitat (corridors) facilitating the movement and dispersal of the pathogen. Leyland cypress was found to be severely affected by bark canker throughout California when planted at a distance from the coast, and worldwide reports have shown that this tree is prone to attack and disfigurement by cypress canker in conducive areas. Vulnerability of Leyland cypress is due to its marked susceptibility to cypress canker and to the genetic uniformity which is perpetuated by the agamic propagation of few genotypes.

The occurrence of virulent and spreading infections on Leyland cypress is in contrast to the endemic (or post-epidemic) phase that $S$. cardinale canker is currently exhibiting on common cypress in Italy. Since any kind of host specialization or different pathogenicity between S. cardinale isolates from common and Leyland cypress has been excluded [28], the inoculum of the fungus that is progressively increasing in the diseased Leyland cypress plantations might favor the spread of the disease to the local common cypress and foster new outbreaks. 


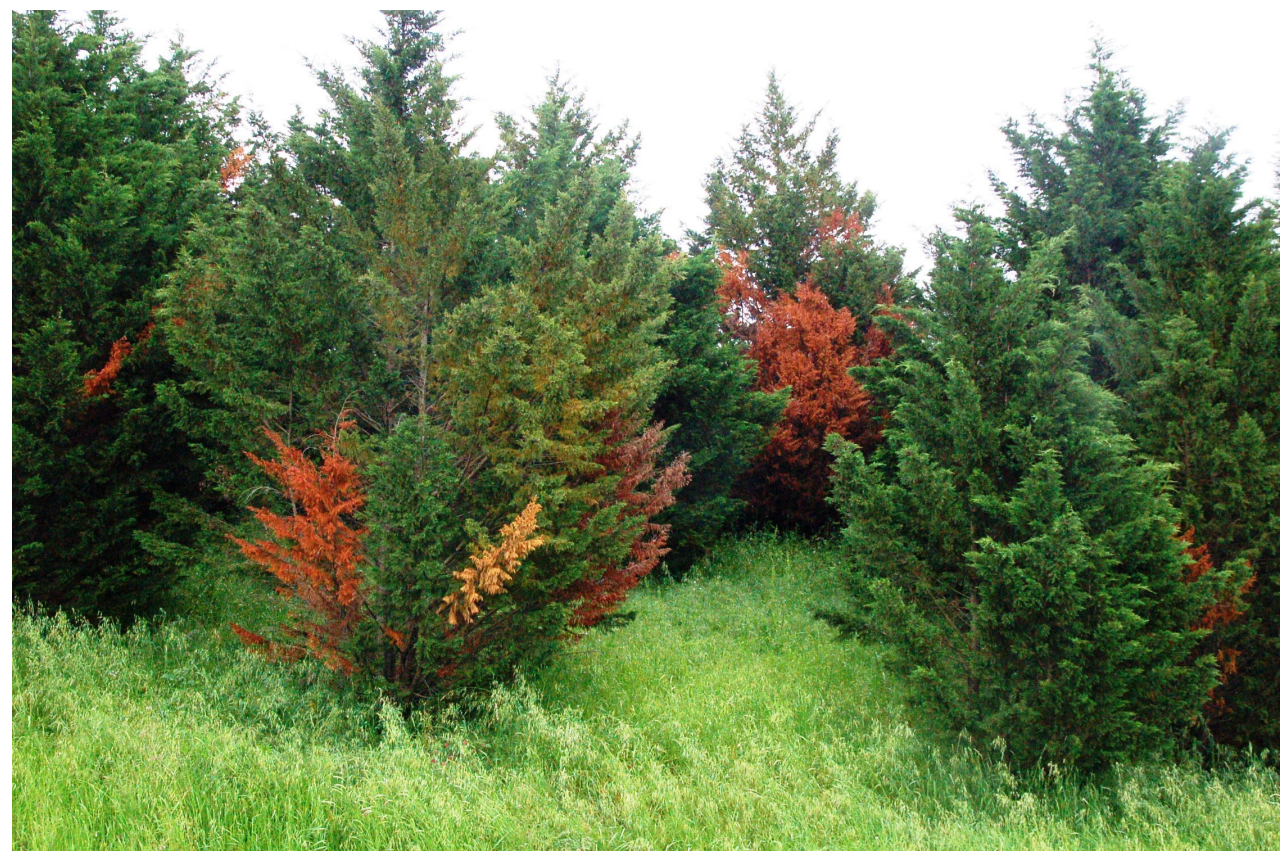

Figure 10. The hybrid $\times$ Cup. leylandii is a hyper-susceptible host of $S$. cardinale which could represent a reservoir of inoculum that may influence the propagule pressure of the pathogen (Rosignano, Tuscany, 2013).

\section{Disease Management of CCD in California and in the Mediterranean}

Different approaches are generally required depending on the context in which the host plants are to be protected from CCD. Plantations with a landscape value, which also may have an historical and monumental importance, require a more conservative approach to preserve their ornamental and aesthetic value as much as possible (Figure 11). In cypress woods, the only possibility is the felling and removal of infected trees due to obvious operational limitations (Figure 12).

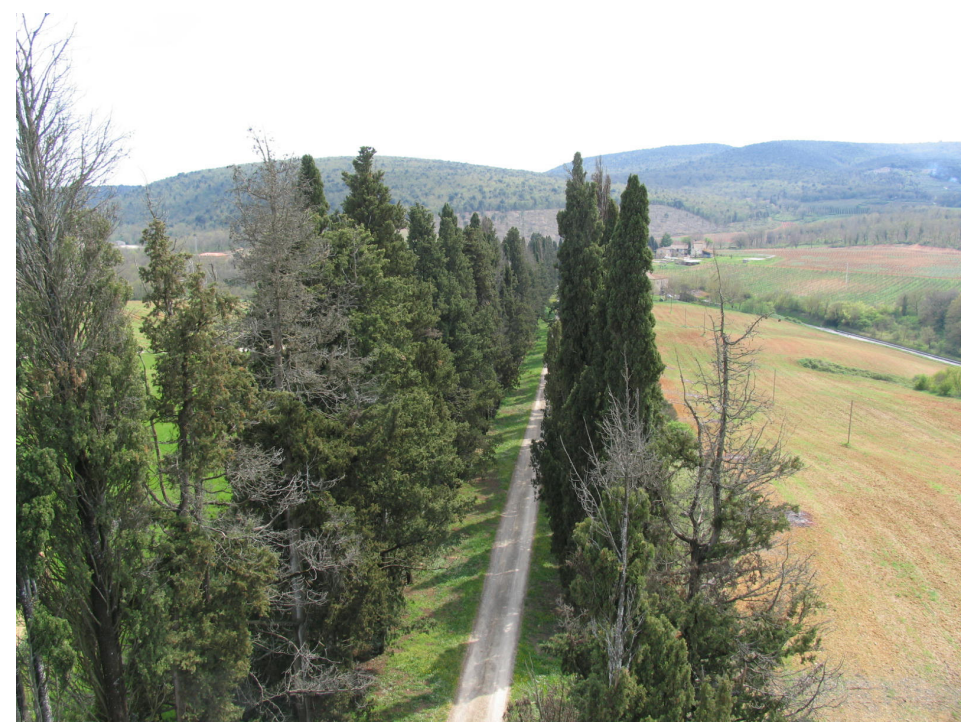

Figure 11. Sanitation of plantations with a historical and monumental value required a conservative approach to preserve their ornamental value, but only repeated interventions were effective to control the CCD (Monteriggioni, Tuscany, 2012). 


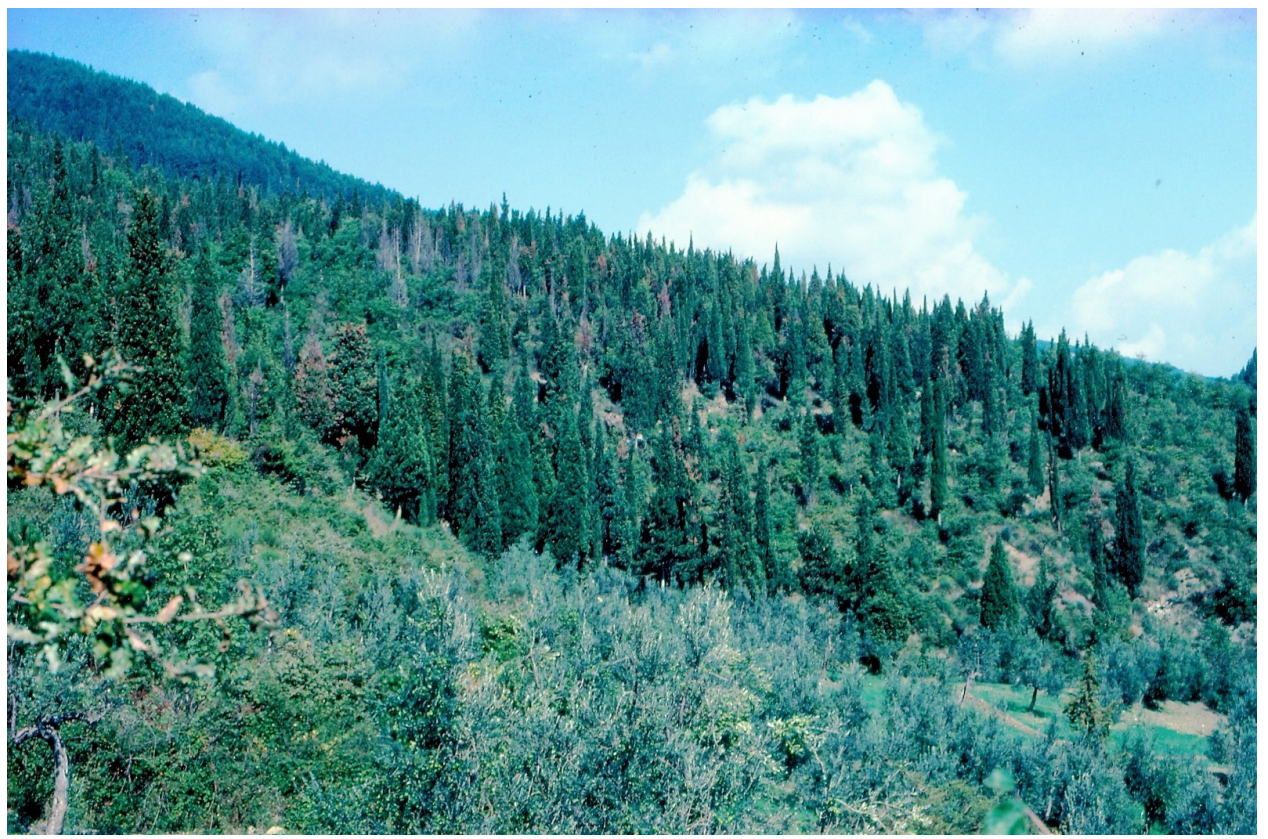

Figure 12. The incidence of CCD in cypress stands was severe in the Florence surroundings in the 1990s (Monte Morello, Tuscany, 1995).

\subsection{CCD Control in California: A Drastic Strategy}

In California, following the rapid development of epidemics that in less than 10 years had severely injured most of the Monterey cypress plantations in inland districts, drastic measures were implemented to control the disease. All the plantations in sensitive areas were dismantled, and as a preventive measure, planting of susceptible hosts over large surfaces was discouraged. This choice has enabled optimization of the extinctive mechanical control method, minimizing the build-up of pathogen inoculum. The beneficial effects of this strategy have led to sustained results, and are still visible. Cypress canker is currently present as an endemic disease in California, and the lack of sufficient density and continuity of susceptible hosts has prevented the occurrence of new epidemic outbreaks. The policy of not planting cypress species susceptible to bark canker over large surfaces has represented a form of disease control, capable of minimizing the build-up of the pathogen inoculum; and the lack of continuity of host species has probably limited the spread of disease in the following years. Host density is recognized as a major factor driving disease epidemics, and some studies have determined a threshold below which a pathogen cannot invade a population of susceptible individuals [53,54].

As bark canker continues to be a constraint for cypress cultivation in California, effective management procedures and the use of resistant host material should help to reduce its overall impact and to use cypress successfully, although genetic resistance to CCD has been found exploitable only in C. sempervirens, but not in C. macrocarpa or $\times$ Cup. leylandii $[28,55,56]$.

\subsection{CCD Control in the Mediterranean: An Integrated Disease Management Strategy}

In the Mediterranean (and particularly in central Italy), the massive and extended presence of the susceptible host and the unique and irreplaceable ornamental, historic, and recreational value of cypress have required extreme caution in adopting proper control measures. Besides reducing the inoculum of the fungus, interventions had to maintain the primary role of cypress in the landscape.

The disease control strategy in Italy has been based on the integration of different methods: extinctive measures, through extensive sanitation throughout the territory; preventive chemical 
treatments in nurseries and young plantations, and use of selected cypress lines by conducting a breeding program for resistance.

Sanitation is the main direct method for controlling cypress canker; this consists of the extinction on a vast scale of sources of the pathogen inoculum through the removal of all infection sources. This is practically attained by felling all of the compromised or killed trees and pruning the partially affected crowns, providing that all the resultant infected material is destroyed by fire.

The effectiveness of sanitation is related to the reduction of the inoculum load that careful and extended interventions are able to attain by removing all sources of infection over a wide area. In Tuscany, execution of sanitation throughout the entire territory was considered to be difficult, due to the huge economic and human resources that had to be employed. This discouraged the start of large-scale sanitation campaigns, so the first interventions supported by public funds were performed only in 1974, more than 20 years after the first report of the disease.

As it was impossible to protect all the cypress trees in the whole region with sanitation, in the following decades, a priority program was planned. Sanitation was therefore preferentially focused on the cypress plantations which had the highest landscape, historical, and biological value.

Sanitation has been performed following two different approaches: in the woods, all affected cypresses have been felled, irrespective of how they were diseased, as pruning of crowns would involve obvious operational difficulties. Instead, in plantations that have an ornamental and historic role (rows, groups, hedges, single trees), only the compromised or killed trees were felled, while crowns that were affected to a limited extent were subjected to pruning. This has been done in an attempt to preserve the aesthetic and ornamental appearance of these vegetal structures (conservative sanitation).

These two different approaches to sanitation have shown a quite different effectiveness over the years. Sanitation has produced good results in the woods, where the removal of all the infected trees led to a significant and enduring reduction of the incidence of the disease. In ornamental plantations, however, the results of the pruning interventions were often not as good as expected due to the need to preserve the affected trees. Indeed, the identification of all current infections is not an easy task, particularly on large stems and branches, and the proper execution of cuts is not obvious, because it is necessary to remove all infected tissues and not just the drying organs (branches or stems).

Herein are reported two different cases, outlining the different results obtained by sanitation following the two different approaches. The adoption of a conservative sanitation in ornamental plantings has often been moderately effective. Although useful in reducing the inoculum sources of the pathogen, it has rarely been shown to remove all of the developing infections. The rows of cypresses have then often continued to be corridors for the spread of the disease, even after being subjected to sanitation.

\subsubsection{Ornamental Plantations: The Case of the "Viale di Bolgheri"}

The case of the famous cypresses of the Viale di Bolgheri (Tuscany, Italy) [57] is representative of how difficult controlling CCD through conservative sanitation may be-particularly in highly conducive sites. The Viale di Bolgheri is a straight, $5 \mathrm{~km}$ long road flanked by two rows of (originally) 2400 century-old cypresses located in the coastal area of Tuscany, south of Leghorn, considered part of the legally protected artistic and cultural heritage. Here the impact of the disease has always been severe due to microclimatic conditions particularly favorable to $S$. cardinale development (high humidity of the coastal area) and also due to the trees being arranged close to one another in rows that have promoted the spread of infections throughout the plantation. The Viale di Bolgheri is the only case (among ornamental plantations) in which a detailed constant monitoring of the spread of cypress canker has been carried out for years in the course of a long-term project for the preservation of the Viale. Sanitation here was conducted following a strict conservative approach due to the great historical and cultural importance of the plantation.

Since 1999, 12 surveys have been conducted (the last in 2015) to monitor the health of each cypress of the Viale. During this 16-year period, seven sanitation campaigns were carried out (Table 4). 
Based on the extent of diseased crown, sanitation was intended to prune partially affected trees and to remove all trees where recovery was not possible. As an additional measure, sanitation was also extended to surrounding areas (within $2 \mathrm{~km}$ from the Viale) to create a protective belt by lowering the fungus inoculum load.

Table 4. Time series of the interventions aimed at the control of CCD in the monumental cypress tree-lined road "Viale di Bolgheri".

\begin{tabular}{|c|c|c|c|c|c|c|c|}
\hline & $\begin{array}{l}\text { Number of } \\
\text { Trees in the } \\
\text { "Viale" }\end{array}$ & $\begin{array}{l}\text { Total } \\
\text { Infected } \\
\text { Trees (\%) }\end{array}$ & $\begin{array}{l}\text { Trees } \\
\text { Felled } \\
(\%)\end{array}$ & $\begin{array}{l}\text { Trees } \\
\text { Pruned } \\
(\%)\end{array}$ & $\begin{array}{l}\text { Trees Pruned } \\
\text { More than one } \\
\text { Time }(\%)\end{array}$ & $\begin{array}{l}\text { Extent of } \\
\text { Damaged } \\
\text { Crown (\%) }\end{array}$ & $\begin{array}{l}\text { Newly } \\
\text { Infected } \\
\text { Trees (\%) }\end{array}$ \\
\hline January 1999 & 2374 & 21.7 & 4.0 & 17.7 & - & - & - \\
\hline July 2001 & 2374 & 22.0 & 5.1 & 16.9 & - & - & - \\
\hline April 2002 & 2254 & 11.4 & 2.3 & 9.1 & - & 9.8 & - \\
\hline January 2005 & 2203 & 14.3 & 3.2 & 8.5 & 10.9 & 6.0 & - \\
\hline September 2006 & 2172 & 11.8 & 1.0 & 10.8 & 39.5 & 10.9 & 60.5 \\
\hline March 2007 & 2146 & 5.6 & 0.4 & 5.2 & 63.9 & 5.5 & 36.1 \\
\hline December 2007 & 2138 & 6.5 & 0.1 & 6.3 & 68.1 & 6.5 & 31.9 \\
\hline November 2008 & 2135 & 11.4 & 0.6 & 10.9 & 77.7 & 8.6 & 22.3 \\
\hline September 2010 & 2123 & 12.8 & 1.6 & 11.2 & 74.6 & 8.3 & 25.4 \\
\hline May 2013 & 2088 & 12.2 & 1.4 & 10.7 & 80.2 & 14.1 & 19.7 \\
\hline November 2013 & 2058 & 1.9 & 0.1 & 1.8 & 89.1 & 8.4 & 10.9 \\
\hline November 2015 & 2056 & 8.2 & 0.9 & 7.3 & 87.0 & 15.2 & 5.2 \\
\hline Since January 2016 & $\begin{array}{l}2027 \\
(-14.6 \%)\end{array}$ & - & - & - & - & - & - \\
\hline
\end{tabular}

The repeated sanitation campaigns led to a gradual reduction of disease incidence which decreased from $22 \%$ in 2001 to $8.2 \%$ in 2015. Due to the numerous felling, the number of trees in 2015 was $14.6 \%$ lower than in 1999 (more than 347 out of 2374). Both the amount of trees to be felled and the number of trees to be pruned decreased progressively due to the parallel reduction of disease incidence and the decrease of the inoculum load in the Viale (Table 4). Similarly, the number of newly infected trees decreased to $5.2 \%$ in 2015 , while the number of previously pruned trees showing the recurrence of new symptoms increased to $87 \%$. These results underline the success of recurrent sanitation in reducing the spread of infections to healthy trees, and simultaneously, the difficulty of eradicating the disease by conservative pruning interventions in old and large trees, also evidencing how $S$. cardinale infections can remain hidden for years before producing symptoms in large trees.

Generally, a positive correlation was found between the time lapse between two consecutive sanitation campaigns and the number of diseased trees $(r=0.48)$, and it clearly shows that regular surveys and sanitation allowed disease incidence to remain below a "safety" threshold of around $10 \%$ (Figure 13), but that eradication of the disease is difficult. A gap of several years in the sanitation interventions could lead to a resurgence of $C C D$, frustrating the positive results previously achieved.

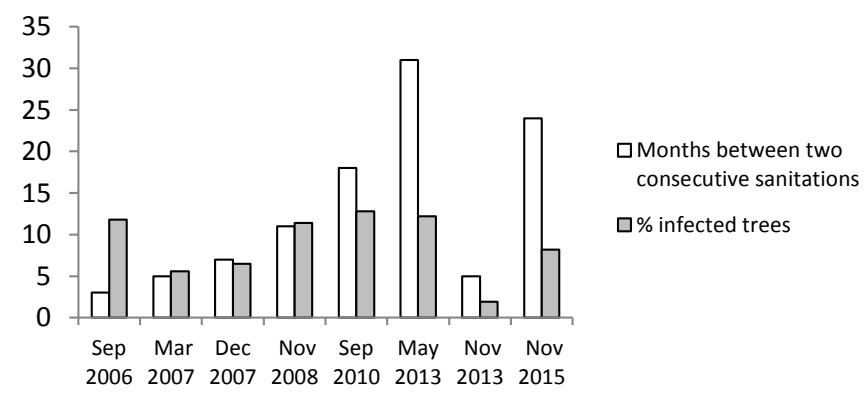

Figure 13. Effect of repeated sanitation campaigns on the CCD incidence in the "Viale di Bolgheri" (Tuscany, Italy). 


\subsubsection{Sanitation in Cypress Woods: The Case of the Florence Surroundings}

The effectiveness of sanitation in cypress woods was evident in a trial performed in three pure cypress stands in the Florence area [58]. In 1982 the mean disease incidence in the three stands was $37.5 \%$. In 1983 a portion in each stand was subjected to sanitation (each infected tree was felled and removed) while the remaining part was left untreated. Every two years, from 1985 to 1993, the number of newly infected trees was evaluated in both treated and untreated portions of the three cypress stands, separately recording the incidence of diseased trees (Figure 14). Results indicated a high degree of effectiveness of sanitation in all three stands. Ten years after sanitation, the incidence of disease in the treated plots ranged between $3.4 \%$ and $6.2 \%$, while in the untreated area, the percentage of newly diseased trees ranged between $17.5 \%-23.5 \%$. A clear difference in the mean annual spread rate of CCD (as a percentage of newly infected trees) emerged between the untreated stands (4.5\%) and the plots subjected to sanitation (1\%). The effect of reduction of the inoculum load through sanitation on the occurrence of new infections in the following years is clearly demonstrated.

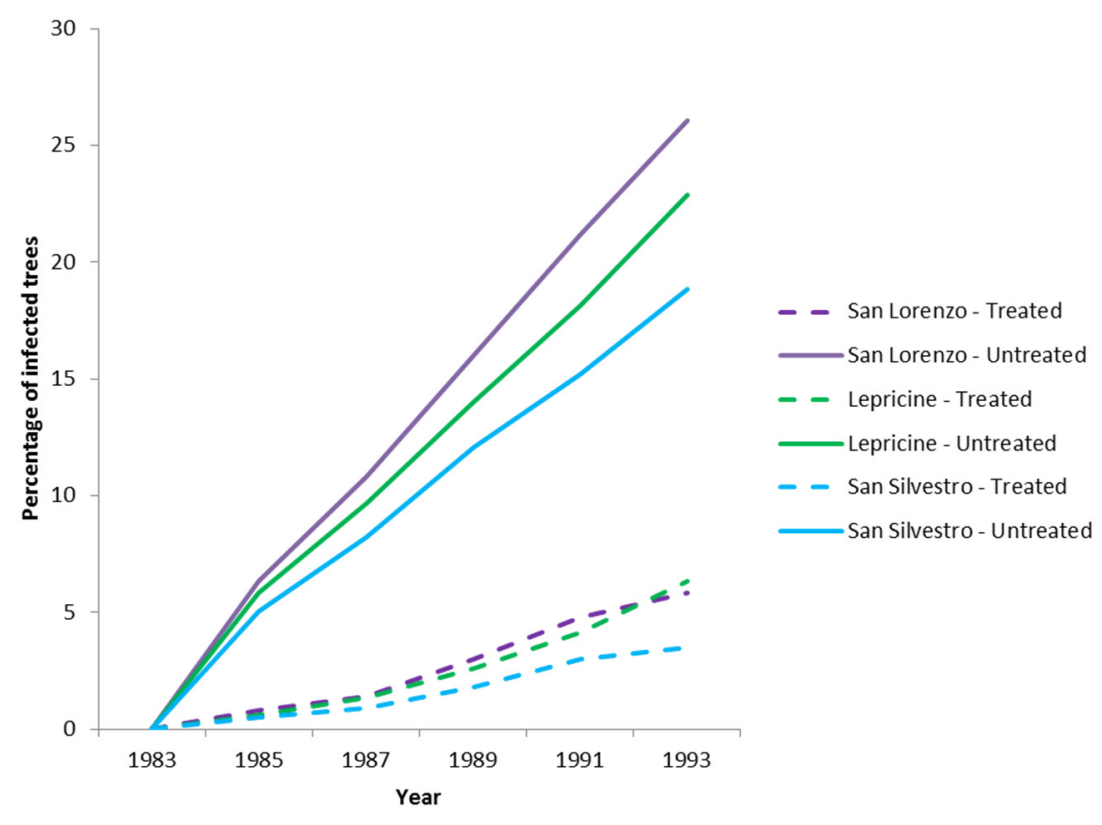

Figure 14. Effect of sanitation on the annual spread rate of CCD (\% of newly infected trees) in three cypress woods (San Lorenzo, Lepricine, and San Silvestro) located in the surroundings of Florence compared with untreated neighboring areas. The disease incidence was normalized to zero at the beginning of the experiment (1983) (adapted from [58]).

Sanitation is also capable of increasing the genetic value of forest stands-particularly seed woods-by the removal of susceptible trees, thus accelerating natural selection and increasing the proportion of resistant trees.

From the above, it appears that sanitation in Tuscany could not be as drastic and incisive as the severity of epidemics would have required. Nevertheless, along with the other control measures adopted on a large scale, in the long-term, it contributed to a reduction in the inoculum of the fungus, gradually slowing the spread and intensity of epidemics, promoting natural evolution towards an endemic equilibrium.

\subsection{Breeding for Resistance}

As a complement to sanitation and chemical prevention, a genetic improvement program of cypress for resistance to S. cardinale bark canker was begun in the 1970s to tackle the rapidly spreading 
epidemics that were threatening woods, windbreaks, and ornamental plantings, and were spoiling the landscape in Tuscany and in other Mediterranean regions.

At first, extensive inoculation trials on plants derived from commercial seed (gathered from the seed woods) and on the half-sib progenies derived from healthy candidates sampled in the foci of infection of the disease in central Italy revealed that $88 \%$ of the trees were susceptible, $10 \%$ were tolerant, and only $1 \%-2 \%$ were resistant [55]. No differences were found between the populations of individuals derived from commercial seeds and the half-sib progenies of (about 200 families) derived from seeds gathered from healthy candidates selected in the foci of infection of the disease in Tuscany. Similar results were obtained from inoculation trials on different provenances sampled in the native range of $C$. sempervirens in Greece [59].

Instead, a distinct response to inoculations was clearly evident among the different cypress species. Cupressus macrocarpa and the other North American species included in the same phylogenetic group, such as C. ambramsiana Wolf, C. goveniana (Gordon) Bartel, C. pygmaea (Lemmon) Sarg, were found to be very susceptible. Cupressus sempervirens, C. arizonica Greene, C. sargentii Jeps, C. macnabiana, C. stephensonii Wolf were found to be susceptible. Instead, C. glabra (Sudw.) Little and C. bakeri, in addition to the Asian and North-African species, showed a good level of resistance to bark canker [56-60].

The cypress defense response to $S$. cardinale infections is known to be based on the formation of the necrophylactic periderm activated by the host to compartmentalize the damaged tissues, and is not a specific response to the pathogen. The vigor of this reaction determines the resistance level of a cypress tree to bark canker, as only plants that are able of setting up effective barriers and then compartmentalizing the infected tissues can succeed in repairing the lesion. So, the mechanism which governs the reaction of cypress to $S$. cardinale infections is under polygenic control, and its phenotypic expression can be influenced by both the host genotype and environment. On the other hand, this polygenic resistance based on the additive effects of several genes is more difficult for the pathogen to overcome [61].

The variability of the response to bark canker estimated in $C$. sempervirens was thought to be sufficient for undertaking a genetic improvement program aimed at selecting a wide genetic base of canker-resistant lines without the need to introduce resistant genes from other cypress species through interspecific crosses.

Currently, more than 100,000 accessions are included in the Institute for Sustainable Plant Protection-National Research Council of Italy (IPSP-CNR) germplasm collection (covering more than 60 hectares) which has been set up by Institute for Sustainable Plant Protection over four decades in various sites in central Italy and other Mediterranean countries. During this period, more than 400 canker-resistant $C$. sempervirens genotypes were selected, including eight patented clonal varieties $[28,62,63]$. Four of them have been marketed since 1995, with about 30,000 patented cypresses sold each year by the nurseries which hold the license for production. Indeed, some hundred thousand resistant cypress trees have been purportedly planted in central Italy in the last two decades. It is difficult to infer the actual contribution to reducing the reproduction and spread of the pathogen that these resistant genotypes might have played, but their role in decreasing the inoculum load of the fungus has certainly not only been theoretical.

\section{Genotypic and Phenotypic Variation of California and Mediterranean S. cardinale Populations}

A comparative analysis of the genetic diversity of $S$. cardinale populations from different areas was conducted to determine the relationships among these populations and to infer the source of the pathogen [33]. Source populations are hypothetically more diverse, while derived (introduced) populations are less diverse and nested within source populations due to bottleneck and founder effects.

Based on 7 simple sequence repeat (SSR), indices of genotypic and genetic diversity were found to be always higher for the Californian (Cal) than for the Mediterranean (Med) populations. The 
higher genetic diversity of the Cal population is also supported by sequencing of the $\beta$-tubulin region, which revealed the presence of two distinct haplotypes within the $S$. cardinale population in Cal, whereas only one of the two haplotypes was present among isolates from the Med. According to amplified fragment length polymorphism (AFLP) data, the two $\beta$-tubulin haplotype groups of the Cal population clustered separately in a PCA analysis [34]. This suggests that the two haplotypes are not simply two different alleles at one locus, but may be associated with two distinct groups of isolates potentially characterized by genotypic and phenotypic differences.

SSR genotyping also revealed that alleles appeared to be randomly associated in the Cal population, whereas a significant linkage disequilibrium was found for the Med population, suggesting that sexual reproduction may be ongoing in California, while a clonal reproduction characterizes the Mediterranean population [33]. A different way of reproduction seems to be confirmed by the fact that in Cal, the same genotype was found only twice at significant distances compared to 48 times in the Mediterranean. It is worth noting that $S$. cardinale is still considered to be an anamorphic fungus reproducing agamically, as its perfect stage-ascribed to the ascomycete Leptosphaeria_was reported on dying and dead cypress trees in north central California only once, but was not fully recognized because it was only partially described [64].

Network analysis (MSN) based on SSR multilocus genotypes and Neighbour-Joining analysis of AFLP both suggest that the Cal population of the fungus represented a source for the Med invasion [34]. In fact, isolates from California and the Mediterranean formed two distinct clusters of genotypes. A single connection between the two clusters through a series of three genotypes exclusively present in central Italy leads us to infer that a single introduction event from Cal into central Italy likely gave rise to the Med population of the fungus.

Structure analysis based on AFLP loci modeled the Mediterranean population as containing two clusters (called Med 1 and Med 2). The Med 1 population would include the founder Mediterranean population (directly derived from California), while the Med 2 population would derive from Med 1 and may be the result of a genetic process which led to a distinct population that then expanded in the Mediterranean [34].

Actually, the genotypic identity of isolates coming from locations hundreds kilometers apart suggests that the movement of infected plant material by humans is mainly responsible for pathogen expansion in the Mediterranean. As no clustering of Med isolates based on geography has been observed by PCA analysis, fungal individuals are likely to be moved frequently within this region. Central Italy as the source of the Mediterranean epidemics is also supported by identical AFLP genotypes found in Italy and Greece as well as in Italy and Spain, and by a substantial migration from Italy into Greece. Since no identical genotypes or PCA clustering of isolates from the Mediterranean and California were detected, intercontinental movement of inoculum is rather infrequent, as also confirmed by the lack of significant migration between the two areas [33].

Variation of phenotypic traits of the introduced Mediterranean population of S. cardinale derived from the movement and settlement of the fungus from the California source population was studied to evaluate the adaptive evolution of the pathogen during the invasive process [35]. Variability (phenotypic plasticity) of a set of characteristics considered important for establishment, infection, and spread of the pathogenic fungus were studied to determine which characteristics may favor the invasion and which are in rapid evolution. In the invasive Mediterranean population Med 1 , traits associated with increased transmission and spread seemed to be favored in comparison to traits such as virulence and greater competitiveness. Thus, a smaller size of conidia and abundant sporulation are favored, while other traits such as virulence, rapid spore production, and germination are seemingly not selected during the invasive process. The source population (California) and the invasive (Mediterranean) population were phenotypically distinct (based on PCA analysis). Isolates of California showed greater aggressiveness (in terms of lesion length), a higher growth rate, a greater sporulation and germination capacity, and produced conidia of larger size. Nevertheless, in spite of the reduced genetic variability exhibited by the Med population compared to the Cal population, all 
of the considered characteristics showed a greater plasticity (wider range of variation) in the Med 1 population (i.e., during the first phase of invasion) than in the source Cal population. So, the phenotypic plasticity would have had a significant role in the first phase of invasion, while it would have been less important as the invasive population adapted to the new environment, as found in the isolates of the Med 2 population derived from Med 1.

\section{Impacts, Risks of CCD, and Future Research Needs}

The impacts attributable to the CCD where it attained an epidemic behavior have been: (a) effects on growth, survival, and abundance of the host species; (b) impacts on ecological functions of cypress woods as CCD altered disturbance regimes such as flammability, changes in hydrology, and soil erosion; (c) impacts on human social life because the presence of trees disfigured by the disease caused unpleasant feelings of degradation that were highly perceptible in environments of high landscape, historical and cultural, or recreational value.

As previously described, after its introduction from California, S. cardinale invasion in the Mediterranean has been subject to an evolution process over a 60-year period. A first epidemic phase occurred in the first two decades following its introduction, and had central Italy as center of gravity. Then, starting from the 1980s, epidemics expanded to cover the whole Mediterranean region. From the beginning of the 21st century, cypress canker gradually reached an endemic equilibrium (based on high disease incidence), also helped by the control measures extensively adopted in some regions.

Genetic information points to a significant isolation of the two populations, and identifies California as the center of diversity of the pathogen. Isolation and a separate evolution is also supported by different reproductive strategies and distinct phenotypic traits of the two populations. In view of these differences, plant quarantine regulations should be directed toward preventing further introductions of new strains or different lineages of the pathogen from California.

Introduction of new genetically different genotypes of the fungus in the Mediterranean could change the course of the epidemic, increasing the level of genetic variability available for selection in the new environment. Introduction and establishment of genotypes with novel mating alleles might give rise to sexual reproduction by bringing together different genetic combinations, thus increasing the pathogenicity and the level of adaptive evolution of the invasive population.

Isolates from California have also demonstrated a higher virulence, an increased growth rate, a greater adaptability to a wider range of temperatures, and greater reproductive capacity (sporulation and germination) compared to the Mediterranean isolates [35]. So, new introductions from California to the Mediterranean could have serious consequences for the local common cypress populations that survived the previous epidemics, causing a higher mortality rate and eventually new disease outbreaks. Introduction of genotypes adapted to a wider range of temperatures would cause a further expansion of the population of the pathogen to warmer and colder areas of Europe.

Shifts in the course of epidemics have been reported in other pathosystems due to intraspecific genetic recombination or gene flow among different lineages, as occurred in Phytophthora ramorum [65] and P. infestans [66] via interspecific hybridization, as was observed in the case of Ophiostoma novo-ulmi [67] and Phytophthora alni [68]. Alternatively, faster evolution and adaptation of newly introduced isolates to different environments may increase the spread of epidemics, as reported by Robin et al. [69] for Cryphonectria parasitica.

The regulatory systems of most countries generally do not easily allow for a distinction between groups of genotypes within a same species, and control regulations are relaxed when the same species is reported in two different countries. This underlines a considerable weakness of current international policies aimed at limiting the introduction of invasive species.

Introduction of new $S$. cardinale genotypes from California to the Mediterranean could also frustrate the results of a long-term breeding program which has led to the selection of a series of canker-resistant cypress genotypes. The selected resistance could be overcome by more aggressive 
genotypes of the pathogen. The durability of the selected resistant lines is crucial to the prevention or minimisation of the introduction of different genotypes of the fungus from California.

It could be useful to evaluate whether the cypress lines selected in Italy which have shown resistance against the Mediterranean isolates of $S$. cardinale are able to maintain their resistance to the most aggressive isolates from California. Actually, in California, a trial has already been started to assay the response of some canker-resistant cypress genotypes selected in Italy. If results are successful (i.e., if the tested cypress clones are confirmed to be resistant even towards the most aggressive isolates of California), their use for new plantations will be practicable, provided they are well adapted to the environmental conditions of California. If the greater aggressiveness of the isolates from California will be able to overcome the resistance of the selected clones, prevention of new introductions from this area in the Mediterranean will be imperative. This would also mean that the basic level of resistance of the cypress populations that experienced previous outbreaks in the Mediterranean will not able to prevent the development of new outbreaks of the disease. The increased aggressiveness and reproductive capacity exhibited by the isolates from California could enhance their intraspecific competitive ability, allowing them to establish within the invasive Mediterranean population of the fungus.

In the context of the control of cypress canker, management of hyper-sensitive host species which may represent a reservoir of fungal inoculum is not a minor issue. The marked worldwide vulnerability to cypress canker exhibited by Leyland cypress underlines the fact that this tree is unsuited to areas where conditions are conducive to the spread of $S$. cardinale. Leyland cypress can be used successfully in cooler climates not suited for the pathogen. In central Italy, there is the real risk that the severely cankered plantations of Leyland cypress may represent a source habitat for the inoculum of S. cardinale and favor a resurgence of epidemics on the local common cypress. Thus, in Italy and other Mediterranean regions, the use of this tree should be discouraged. Leyland cypress should be replaced with some autochthonous resistant cypress varieties that also have a crown habit suitable for barriers and windbreaks, which have shown a good vigor and adaptability to Mediterranean climatic conditions in the course of previous projects.

Future research should be directed toward monitoring the genetic structure of the pathogen population to highlight as early as possible the evolution of new clonal lineages with greater fitness and adaptability [69] that in a climate change scenario could lead to a geographic shift of the disease [70]. How the expected changes of climatic conditions could influence phenology of cypress and determine phenotypic changes that might alter its susceptibility [71] to CCD is another major topic that requires investigation.

To prevent further introductions of $S$. cardinale, it is important to fully understand through which routes human activities are promoting the long-range dispersal of the pathogen. Equally important is verification of whether California actually represents the worldwide source of $S$. cardinale by further comparison with populations the fungus from other areas of the world.

Acknowledgments: The authors wish to thank all the colleagues at IPSP-CNR who have worked diligently to study and protect Cypress, guided by a deep respect for this tree. In particular: Paolo Raddi, Alberto Panconesi, Vincenzo Di Lonardo, Giovanni Torraca, Anna Romagnoli. We also thank Matthew Haworth for his critical reading of the manuscript.

Author Contributions: R.D. is the primary author of this paper and conducted the literature review. G.D.R. is the corresponding author and contributed equally to the writing, editing and review of the relevant literature.

Conflicts of Interest: The authors declare no conflict of interest.

\section{References}

1. Keller, R.P.; Cadotte, M.W.; Sandiford, G. Invasive Species in a Globalized World: Ecological, Social, and Legal Perspectives on Policy; Keller, R.P., Cadotte, M.W., Sandiford, G., Eds.; The University of Chicago Press: Chicago, IL, USA, 2014; pp. 1-20.

2. Luque, G.M.; Bellard, C.; Bertelsmeier, C.; Bonnaud, E.; Genovesi, P.; Simberloff, D.; Courchamp, F. The 100th of the world's worst invasive alien species. Biol. Invasions 2014, 16, 981-985. [CrossRef] 
3. Gonthier, P.; Faccoli, M.; Garbelotto, M.; Capretti, P. Invasioni biologiche ed effetti sulla biodiversità forestale-Bioinvasions and their effects on the forest biodiversity. In Proceedings of the Second International Congress of Silviculture, Florence, Italy, 26-29 November 2014; Ciancio, O., Ed.; Atti Accademia Italiana di Scienze Forestali: Florence, Italy, 2015; Volume II, pp. 155-160.

4. Gonthier, P.; Garbelotto, M. Reducing the threat of emerging infectious diseases of forest trees-Mini Review. CAB Rev. 2013. [CrossRef]

5. Santini, A.; Ghelardini, L.; Pace, C.D.; Desprez-Loustau, M.L.; Capretti, P.; Chandelier, A.; Hantula, J. Biogeographical patterns and determinants of invasion by forest pathogens in Europe. New Phytol. 2013, 197, 238-250. [CrossRef] [PubMed]

6. Pimentel, D.; Lach, L.; Zuniga, R.; Morrison, D. Environmental and economic costs of nonindigenous species in the United States. BioScience 2000, 50, 53-65. [CrossRef]

7. Pimentel, D.; McNair, S.; Janecka, J.; Wightman, J.; Simmonds, C.; O'Connell, C.; Wong, E.; Russel, L.; Zern, J.; Aquino, T.; et al. Economic and environmental threats of alien plant, animal, and microbe invasions. Agric. Ecosyst. Environ. 2001, 84, 1-20. [CrossRef]

8. Pimentel, D.; Zuniga, R.; Morrison, D. Update on the environmental and economic costs associated with alien-invasive species in the United States. Ecol. Econ. 2005, 52, 273-288. [CrossRef]

9. Nentwig, W.; Bacher, S.; Pyšek, P.; Vilà, M.; Kumschick, S. The generic impact scoring system (GISS): A standardized tool to quantify the impacts of alien species. Environ. Monit. Assess. 2016, 188, 1-13. [CrossRef] [PubMed]

10. Panconesi, A. Pathological disorder in the Mediterranean basin. In Agrimed. Reserach. Programme., Progress in EEC Research on Cypress Disease; Ponchet, J., Ed.; Commission of the European Communities: Brussels, Belgium; Luxembourg, 1990; pp. 54-81.

11. Graniti, A. Cypress canker: A pandemic in progress. Annu. Rev. Phytopathol. 1998, 36, 91-114. [CrossRef] [PubMed]

12. Danti, R.; Della Rocca, G.; Panconesi, A. Cypress Canker. In Infectious Forest Diseases; Gonthier, P., Nicolotti, G., Eds.; CABI: Wallingford, CT, USA; Oxfordshire, UK; Boston, MA, USA, 2013; pp. 359-375.

13. Wagener, W.W. Coryneum canker of cypress. Science 1928, 67, 584. [CrossRef] [PubMed]

14. Birch, T.T.C. Gummosis diseases of Cupressus. macrocarpa. N. Z. J. For. 1933, 3, 108-113.

15. Barthelet, J.; Vinot, M. Notes sur les maladies des cultures méridionales. Annu. Epiphyt. 1944, 10, 18-20.

16. Grasso, V. Un nuovo agente patogeno del Cupressus macrocarpa Hartw. in Italia. Ital. For. Mont. 1951, 6, $63-65$.

17. Saravì Cisneros, R. 1953 Cancrosis de los Cipreses provocada por Coryneum cardinale Wag. en la provincia de Buenos Aires (Argentina). Revista de la Facultad de Agronomia de La Plata (Tercera Epoca) 1953, 29, 107-119.

18. Anastassiadis, B. A new for Greece disease of the Cypress. Ann. BPI 1963, 5, 164-166.

19. Mujica, F.; Vergara, C.; Oehrens, E. Flora Fungosa Chilena, 2nd ed.; Ciencias Agricolas 5, Universidad de Chile: Santiago, Chile, 1980.

20. Torres, J. Grave enfermedad de los cipreses en España. Bol. Serv. Plagas For. 1969, 12, 97-99. (In Spanish)

21. Strouts, R.G. Coryneum canker of Cupressus. J. Plant Pathol. 1970, 19, 149-150.

22. Sutton, B.C. The Coelomycetes; CABI: Eastbourne, UK, 1980; pp. 374-379.

23. Funk, A. Microfungi associated with dieback of native Cupressaceae. in British Columbia. CPDS 1974, 54, 166-168.

24. Caetano, M.F.; Ramos, P.; Pinto-Ganhão, J. The phytosanitary situation of cypress in Portugal and the new prospects. In Il Cipresso: Proposte di Valorizzazione Ambientale e Produttiva nei Paesi Mediterranei della Comunità Economica Europea; Panconesi, A., Ed.; CNR, Regione Toscana, CEE: Florence, Italy, 1991; pp. 81-88.

25. Solel, Z.; Messinger, R.; Golan, Y.; Madar, Z. Coryneum canker of cypress in Israel. Plant Dis. 1983, 67, 550-551. [CrossRef]

26. Wingfield, M.J.; Swart, W.J. Cypress canker in South Africa. In Proceedings of the 5th International Congress of Plant Pathology, International Conference Hall, Kyoto, Japan, 20-27 August 1988; Harvey, I.C., Ed.; p. 361.

27. Danti, R.; Della Rocca, G.; El Wahidi, F. Seiridium cardinale newly reported on Cupressus sempervirens in Morocco. Plant Pathol. 2009, 58, 1174. [CrossRef]

28. Danti, R.; Barberini, S.; Pecchioli, A.; Di Lonardo, V.; Della Rocca, G. The epidemic spread of Seiridium. cardinale on Leyland cypress severely limits its use in the Mediterranean. Plant Dis. 2014, 98, 1081-1087. [CrossRef] 
29. Urbasch, I. Natural occurrence of Seiridium. cardinale on Thuja. in Germany. J. Phytopathol. 1993, 137, $189-194$. [CrossRef]

30. Hennon, P.E. Fungi on Chamaecyparis nootkatensis. Mycologia 1990, 82, 59-66. [CrossRef]

31. Faddoul, J. Contribution à l'étude du Coryneum. cardinale Wag. Morphologie, Biologie, Physiologie; Thèse No. 390; Université Paul Sabatier: Toulouse, France, 1973.

32. Hood, I.A.; Gardner, J.F.; Kimberley, M.O.; Gatenby, S.J.; Cox, J.C. A survey of cypress canker disease. N. Z. Tree Grow. 2001, 22, 38-41.

33. Della Rocca, G.; Eyre, C.A.; Danti, R.; Garbelotto, M. Sequence and simple-sequence repeat analyses of the fungal pathogen Seiridium. cardinale indicate California is the most likely source of the cypress canker epidemic for the Mediterranean region. Phytopathology 2011, 101, 1408-1417. [CrossRef] [PubMed]

34. Della Rocca, G.; Osmundson, T.; Danti, R.; Doulis, A.; Pecchioli, A.; Donnarumma, F.; Casalone, E.; Garbelotto, M. AFLP analyses of California and Mediterranean populations of Seiridium. cardinale provide insights on its origin, biology and spread pathways. For. Pathol. 2013, 43, 211-221.

35. Garbelotto, M.; Della Rocca, G.; Osmundson, T.; Di Lonardo, V.; Danti, R. An increase in transmission-related traits and in phenotypic plasticity is documented during a fungal invasion. Ecosphere 2015, 6, 1-16. [CrossRef]

36. Grasso, V.; Ponchet, J. Historique, distribution géographique et hôtes du Coryneum cardinale Wag. In Proceedings of the 'Seminario Il Cipresso: Malattie e Difesa', Florence, Italy, 23-24 Novembre 1979; Grasso, V., Raddi, P., Eds.; Commission of EC AGRIMED, tipografia l'Artigiano Firenze: Florence, Italy, 1980; pp. 119-126.

37. Wagener, W.W. The canker of Cupressus. induced by Coryneum. cardinale n. sp. J. Agric. Res. 1939, 58, 1-46.

38. Wolf, C.B.; Wagener, W.W. The New World Cypresses; El Aliso, Rancho Santa Ana Botanic Garden: Anaheim, CA, USA, 1948; p. 444.

39. Della Rocca, G.; Danti, R.; Garbelotto, M. First report of Seiridium. unicorne causing bark cankers on a Monterey cypress in California. Plant Dis. 2011, 95, 691.

40. Moriondo, F.; Bonifacio, A. Osservazioni preliminari sul Corineo del cipresso. Atti dell'Accademia dei Georgofili Dispense I-II-III-IV 1968, XV, 211-221.

41. Bartoloni, P.; Panconesi, A.; Intini, M. Il Coryneum Cardinale: Notizie Biologiche e Prospettive di Lotta. In Del Cipresso; Cassa di Risparmio di Firenze, Ed.; Stabilimenti grafici Giunti Marzocco: Florence, Italy, 1976; pp. 49-53.

42. Poggesi, A. Intensità e ripercussioni economiche degli attacchi parassitari di Cornineum (Seiridium) cardinale Wag. e da Cinara cupressi Bckt. sul cipresso comune, con particolare riferimento alla provincia di Firenze. In Proceedings of the 'Seminario Il Cipresso: Malattie e difesa', Florence, Italy, 23-24 November 1979; Grasso, V., Raddi, P., Eds.; Commission of EC AGRIMED, tipografia l'Artigiano Firenze: Florence, Italy, 1980; pp. 135-147.

43. Della Rocca, G.; Di Lonardo, V.; Danti, R. Newly-assessed fungicides for the control of cypress canker caused by Seiridium. cardinale. Phytopathol. Mediterr. 2011, 50, 65-73.

44. Uzielli, A. Il consorzio per la difesa del cipresso. In Del Cipresso; Cassa di Risparmio di Firenze, Ed.; Stabilimenti grafici Giunti Marzocco: Florence, Italy, 1976; pp. 57-59.

45. Accolti Gil, F.; Funaioli, U. Consuntivo della prima campagna d'interventi effettuati nel 1974 in difesa del cipresso in provincia di Firenze. In Del Cipresso; Cassa di Risparmio di Firenze, Ed.; Stabilimenti grafici Giunti Marzocco: Florence, Italy, 1976; pp. 63-66.

46. Panconesi, A.; Raddi, P. Cancro del cipresso aspetti biologici ed epidemiologici . In Il Cipresso: Proposte di Valorizzazione Ambientale e Produttiva nei Paesi Mediterranei della Comunità Economica Europea; Panconesi, A., Ed.; CNR, Regione Toscana, CEE: Florence, Italy, 1991; pp. 49-60.

47. Pivi, R. Primi risultati di un'indagine epidemiologica sul cancro del cipresso in Toscana. In Proceedings of 'Il Recupero Del Cipresso Nel Paesaggio E Nel Giardino Storico' Collodi, Pistoia, Italy, 15 March 1995; Regione Toscana Giunta Regionale Dipartimento Agricoltura e Foreste: Florence, Italy, 1995; pp. 37-43.

48. Feducci, M. Relazioni Tra Parametri Climatico-Ambientali E Diffusione Del Cancro Del Cipresso in Toscana Mediante Applicazioni G.I.S.-G.P.S. Tesi di Laurea di I livello in Scienze Forestali e Ambientali. Facoltà di Agraria; Università Degli Studi di Florence: Florence, Italy, 2003-2004.

49. Xenopoulos, S.; Diamandis, S. A distribution map for Seiridium. cardinale causing the cypress canker disease in Greece. Eur. J. For. Path. 1985, 15, 223-226. [CrossRef] 
50. Rizzo, D.M.; Garbelotto, M. Sudden oak death: Endangering California and Oregon forest ecosystems. Front. Ecol. Environ. 2003, 1, 197-204. [CrossRef]

51. Plantegenest, M.; Le May, C.; Fabre, F. Landscape epidemiology of plant diseases. J. R. Soc. Interface 2007, 4, 963-972. [CrossRef] [PubMed]

52. Tischendorf, L.; Fahrig, L. On the usage and measurement of landscape connectivity. Oikos 2000, 90, 7-19. [CrossRef]

53. McCallum, H.; Barlow, N.; Hone, J. How should pathogen transmission be modelled? Trends Ecol. Evol. 2001, 16, 295-300. [CrossRef]

54. Otten, W.; Gilligan, C.A. Soil structure and soil-borne diseases: Using epidemiological concepts to scale from fungal spread to plant epidemics. Eur. J. Soil Sci. 2006, 57, 26-37. [CrossRef]

55. Raddi, P. Variabilità della resistenza al cancro nell'ambito del cipresso comune. In Proceedings of the 'Seminario Il Cipresso: Malattie E Difesa', Florence, Italy, 23-24 Novembre 1979; Grasso, V., Raddi, P., Eds.; Commission of EC AGRIMED, tipografia l'Artigiano Firenze: Florence, Italy, 1980; pp. 185-193.

56. Andreoli, C.; Ponchet, J. Potential uses of exotic cypress species resistant to canker disease. In Il Cipresso: Proposte di Valorizzazione Ambientale e Produttiva nei Paesi Mediterranei della Comunità Economica Europea; Regione Toscana, CEE, Eds.; CNR: Florence, Italy, 1991; pp. 150-167.

57. Danti, R.; Della Rocca, G.; Barberini, S.; Raddi, P. The historic cypresses of the Viale di Bolgheri: Need of an organic and non-stop action to preserve a living monument. In Proceedings of the 6th International Congress on "Science and Technology for the Safeguard of Cultural Heritage in the Mediterranean Basin" Vol I, Sessions A, C Resource of the Territory, Biological Diversity, Athens, Greece, 22-25 October 2013; pp. 367-374.

58. Panconesi, A.; Danti, R. Esperienze tecnico-scientifiche nella bonifica del cipresso. In Proceedings of 'Il Recupero Del Cipresso Nel Paesaggio E Nel Giardino Storico' Collodi, Pistoia, Italy, 15 March 1995; Regione Toscana Giunta Regionale Dipartimento Agricoltura e Foreste: Florence, Italy, 1995; pp. 9-21.

59. Raddi, P.; Panconesi, A.; Xenopoulos, S.; Ferrandes, P.; Andreoli, C. Genetic improvement for resistance to cypress canker. In Agrimed Reserach Programme, Progress in EEC Research on Cypress Disease; Ponchet, J., Ed.; Report EUR 12493 EN: Brussels, Belgium; Luxembourg, 1990; pp. 127-134.

60. Allemand, P. Relations phylogéniques dans le genre Cupressus (Cupressaceae). In Proceedings of the 'Seminario Il Cipresso: Malattie e difesa', Florence, Italy, 23-24 November 1979; Grasso, V., Raddi, P., Eds.; Commission of EC AGRIMED, tipografia l'Artigiano Firenze: Florence, Italy, 1980; pp. 51-67.

61. Parlevliet, J.E. Durability of resistance against fungal, bacterial and viral pathogens; present situation. Euphytica 2002, 124, 147-156. [CrossRef]

62. Danti, R.; Raddi, P.; Panconesi, A.; Di Lonardo, V.; Della Rocca, G. "Italico" and “Mediterraneo": Two Seiridium cardinale canker-resistant cypress cultivars of Cupressus sempervirens. HortScience 2006, 41, 1357-1359.

63. Danti, R.; Di Lonardo, V.; Pecchioli, A.; Della Rocca, G. 'Le Crete 1' and 'Le Crete 2': Two new Seiridium cardinale canker-resistant cultivars of Cupressus sempervirens. For. Pathol. 2013, 43, 204-210.

64. Hansen, H. The perfect stage of Coryneum. cardinale. Phytopathology 1956, 46, 636-637.

65. Ivors, K.; Garbelotto, M.; Vries, I.D.E.; Ruyter-Spira, C.; Hekkert, B.T.E.; Rosenzweig, N.; Bonants, P. Microsatellite markers identify three lineages of Phytophthora. ramorum in US nurseries, yet single lineages in US forest and European nursery populations. Mol. Ecol. 2006, 15, 1493-1505. [CrossRef] [PubMed]

66. Goodwin, S.B.; Sujkowski, L.S.; Dyer, A.T.; Fry, B.A.; Fry, W.E. Direct detection of gene flow and probable sexual reproduction of Phytophthora infestans in Northern North America. Phytopathology 1995, 85, 473-479. [CrossRef]

67. Paoletti, M.; Buck, K.W.; Brasier, C.M. Selective acquisition of novel mating type and vegetative incompatibility genes via interspecies gene transfer in the globally invading eukaryote Ophiostoma. novo-ulmi. Mol. Ecol. 2006, 15, 249-262. [CrossRef] [PubMed]

68. Brasier, C.M.; Cooke, D.E.L.; Duncan, J.M. Orgin of a new phytophthora pathogen through interpecific hybridization. Proc. Natl. Acad. Sci. USA 1999, 96, 5878-5883. [CrossRef] [PubMed]

69. Robin, C.; Andanson, A.; Saint-Jean, G.; Fabreguettes, O.; Dutech, C. What was old is new again: Thermal adaptation within clonal lineages during range expansion in a fungal pathogen. Mol. Ecol. 2017. [CrossRef] [PubMed] 
70. Bebber, D.P. Range-expanding pests and pathogens in a warming world. Annu. Rev. Phytopathol. 2015, 53, 335-356. [CrossRef] [PubMed]

71. Anacker, B.L.; Rank, N.E.; Hüberli, D.; Garbelotto, M.; Gordon, S.; Harnik, T.; Meentemeyer, R. Susceptibility to Phytophthora. ramorum in a key infectious host: Landscape variation in host genotype, host phenotype, and environmental factors. New Phytol. 2008, 177, 756-766. [CrossRef] [PubMed]

(c) 2017 by the authors. Licensee MDPI, Basel, Switzerland. This article is an open access article distributed under the terms and conditions of the Creative Commons Attribution (CC BY) license (http:/ / creativecommons.org/licenses/by/4.0/). 